Si të Ndërtojmë një Planifikim të Qëndrueshëm të Agregateve

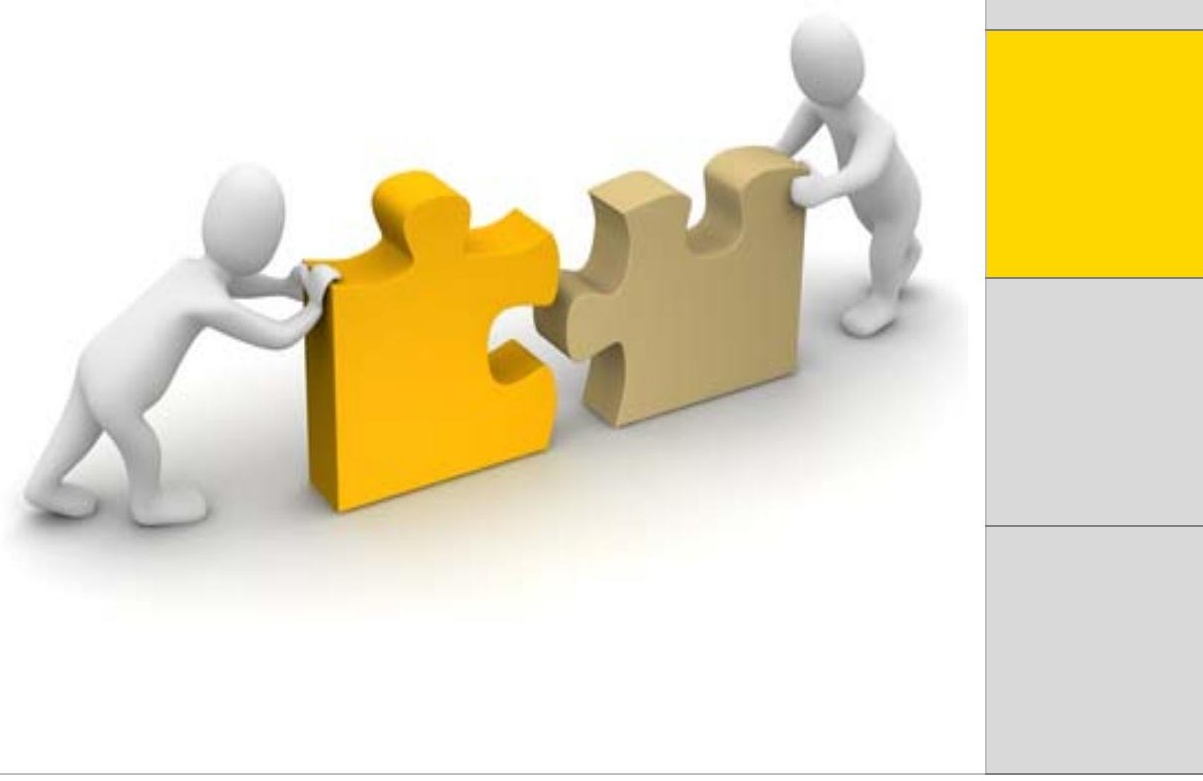

Shtator 2014

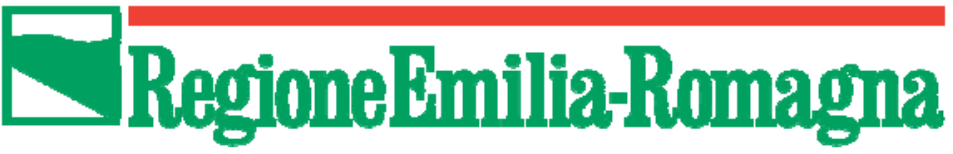





\section{Si të Ndërtojmë një Planifikim të Qëndrueshëm të Agregateve}

\section{Bazuar në:}

Në punën dhe eksperiencën e partnerëve të projektit në Paketën e Punës 6 të Projektit SNAP-SEE "Planifikimi i Qëndrueshëm i Agregateve në Europën Juglindore" (SEE/D/0167/2.4/X)

Website: http://www.snapsee.eu

\section{Paraqitja e Aktivitetit 6.2: Skema e Përgjithshme e Planifikimit Transnacional të Agregateve}

\section{Informacion Publikimi}

Botues \&Menaxhues: Foteini Stathogianni, Urška Dolinar

Vizatimi i kapakut:

Stelios Mavrigiannakis

Printuar:

Sherbimi Gjeologjik i Sllovenise

Viti i botimit 2014

\section{Njoftim}

Ky publikim i SNAP-SEE reflekton vetëm pikëpamjet e autorëve dhe të Autoritetit të Menaxhimit të Programit të Kooperimit Transnacional të Europës Juglindore, nuk është me pergjegjësi ligjore për ndonjë përdorim që mund të bëhet me informacionin që permban. CSNAP-SEE project 2014 
Severi Paolo Geological, seismic and soil survey

Bonzi Luciana Geological, seismic and soil survey

Cintoli Stefano Waste and sites remediation, Water and waste public services and ICT

Marasmi Christian Soil and Coast Protection and Reclamation Service

Ratta Manuela Waste and sites remediation, Water and waste public services and ICT

Rizzati Anna Rita Soil and Coast Protection and Reclamation Service

Romagnoli Massimo Soil and Coast Protection and Reclamation Service

Segadelli Stefano Geological, seismic and soil survey

Furin Stefano Consultant at Geological, seismic and soil survey

\section{Recenzentët}

\begin{tabular}{ll}
\hline Emri & Detyra \\
\hline Shields, Deborah J., Dr. & Colorado State University, United States of America \\
Agioutantis, Zacharias & Technical University of Crete, Greece \\
Tiess, Guenter & Montanuniversität Leoben (University of Leoben), Austria
\end{tabular}

\section{Falenderim}

Partnerët e Projektit SNAP-SEE do të dëshëronin të falenderonin Komisionin Europian për financimin e këtij projekti, që çoi në kooperimin e frutshëm midis partnerëvet, duke ndare pikpamje të ngjashme dhe nje vision të pergjithshëm, qe mundësuan përpilimin e këtij libri dore.

Autorët do të dëshëronin tëfalenderonin kontributin e të gjithë partnerëve në zhvillimin e materiallit tëprezantuar në këtë libër.

\section{Objekti Digital i Identifikimit (DOI)}

doi: $10.5474 /$ snapsee-WP6-SQ

\section{Referimi}

Ky libër dore duhet të citohet në bibliografi me përdorimin e numurt " doi" si më poshtë: Severi et al. (2014), Si të ndërtosh një plan të Qendrueshëm të Agregateve, Projekti SNAP-SEE, http://www.snapsee.eu. Doi:10.5474/snapsee-WP6-EN. 


\section{Si të Ndërtojmë një Plan të Qëndrueshëm të Agregateve}

1 Gjëndja e Planifikimit në SEE.

1.1 Planifikimi i agregateve parësore dhe dytësore ............................................

1.2 Nje përafrim i centralizuar apo një i decentralizuar? .......................................15

1.3 Mbi kompleksitetin e ndërtimit të një plani për resurset minerale ..................19

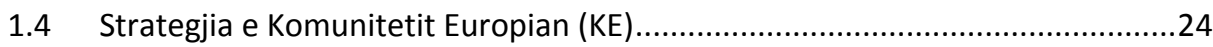

2 Një Hartë e Rrugëve për planifikim ..................................................................25

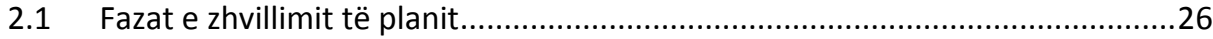

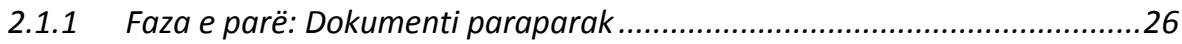

2.1.2 Faza e dytë: Shkëmbimi i informacionit................................................27

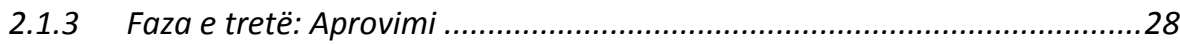

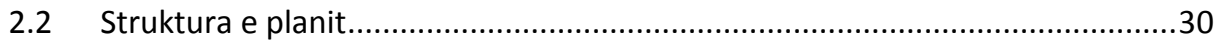

2.2.1 Përcaktimi i nevojave të një plani nacional për resurset e agregateve ......31

2.2.2 Integrimi i planit të agregateve në një plan më të përgjithshëm të

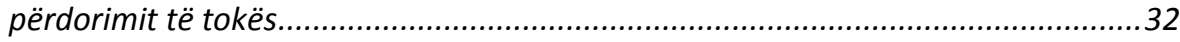

2.2.3 Vendosje e pronësisë të agregateteve parësore........................................32

2.2.4 Referenca tek principet e miratuara në një nivel Europian .........................33

2.2.5 Parashikimi i kërkesave për agregate në të ardhmen .............................34

2.2.6 Identifikimi i prioriteve dhe zonave të mbrojtura ......................................34

2.2.7 Identifikimi i burimeve alternative ........................................................ 36

2.2.8 Përcaktimi i kritereve dhe udhëzimeve për sipërfaqet lokale minerare .....37

2.2.9 Siguro konkurueshmërinë e industrisë të agregateve ............................37

2.2.10 Adoptimi i teknologjive me të mira, të gatshme, gjatë gjithë proçesit.......39

2.2.11 Përcktimi i kritereve për përdorim pas mbylljes ......................................40

2.2.12 Koordinimi i autorizuar midis autoriteteve të lejeve ................................41

2.2.13 Procedurat e lejeve duhet të jenë eficiente dhe efektive............................42

2.2.14 Përforcimi i nevojave për një balancë ambjentale....................................43

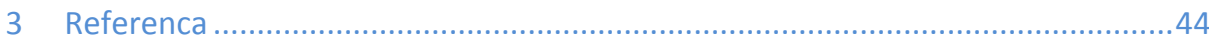




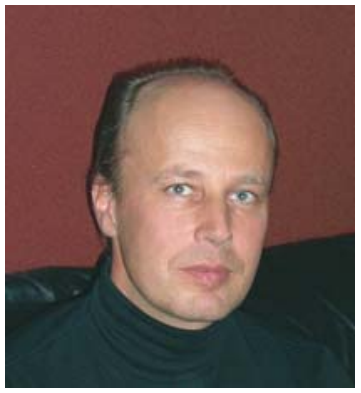

Vendet në Europën Juglindore (SEE), janë të pasura në agregate ndërtimi si gur i therrmuar, zhavorre, rëra, dhe materiale të tjera granulare, që përdoren në industrinë e ndërtimit; por këto resurse, nuk janë të shpërndara në gjithë rajonin, dukë qënë me tepricë në disa zona dhe me mungesë në zona të tjera. Për më tepër që aksesi te këto resurse po shkon veshtiresisht në rritje, në saje të zhvillimeve të tjera infrastrukturore dhe presioneve për ambjentin.

Duke qënë se agregatet janë të rënda dhe të shumta, transporti është i shtrenjtë, prandaj dhe aksesi i resurseve lokale për në treg është i vështirë. Vëndet e Eurpës Juglindore (SEE), në vitin 2020, do të kenë një kërkesë probable rreth $50 \%$ më të lartë, me qëllim që të plotësojnë nevojat e infrastructurës së ndërtimit. Për këtë, është e nevojshme të levizin drejt menaxhimit të qëndrueshëm të resurseve të agregateve (SARM) dhe të bëjnë një furnizim të qëndrueshëm mix (SSM) të rajonit me aggregate, të përmirësojnë efiçencën e resurseve dhe të mbështesin zhvillimin e qëndrueshëm. SARM, është efiçient, me impakt të ulët social-ambjental me karrjerat dhe menaxhimin e mbetjeve, i dubluar me angazhimin e gjërë të grupeve të interesit. Një SSM është kompozuar nga agregate me burime të shumëfishta, përfshi ndërtimin e ricikluar, mbetjet e shkatërrimit, dhe produktet industriale në rrugë e sipër (shëllirat), po ashtu edhe të dy produktet shtëpiake dhe materialet primare të importuara, që sëbashku maksimizojnë rrjetin e të mirave të furnizimit me agregate në breza.

Implementimi i SARM dhe SSM, kërkon një politikë mbështetëse, dhe një kornizë planifikimi. Në saje të diferencave regjionale dhe zhvillimit historik, përafrimet drejt politikës së agregateve, planifikimi dhe menaxhimi, ndryshojnë në nivele të ndryshme politike, brenda SEE dhe vetem në pak raste, ato jane plotësisht të kuptueshme. Përvojat, përfshi politikat dhe planet që ndikojnë në menaxhimin e agregateve, dhe parashikimet që janë përhapur në shumë dokumente të ndryshme, legale, duke bërë koordinimin, janë të vështira të kuptohen.

Ka gjithashtu, një mungesë koordinimi në planifikim për furnizimin me agregate parësore dhe dytësore. SEE kanë mungesë sufuçiente të dhënash për të mbështetur planifikimin e agregateve, kapacite dhe kopetenca të pa mjaftueshme për të marrë përsipër planifikimin e agregateve parësore/ose dytësore, dhe mungesë të theksuar, të pjësëmarrjes të grupeve të interesit në zhvillimin e planeve të zhvillimit të agregateve. Projekti SNAP-SEE i ka adresuar këto defiçite me qëllim që të nxisim rritjen e një industrie vibrante, të qëndrueshme dhe përgjegjëse të agregateve në rajonin e SEE. 
Qëllimi specifik i projektit të Planifikimi të Qëndrueshëm të Agregateve në Europën Juglindore (SNAP-SEE), ishte të krijonte dhe të shpërndante një paketë informimi (Toolbox) për Planifikimin e Agregateve, për të ndihmuar shtetet dhe grupet e interesit në Europën Juglindore (SEE), të bashkëpunojnë për përmirësimin e planifikimit të agregateve dhe menaxhimin e proçeseve. SNAP-SEE u ndërtua mbi rezultatet e Projektit të Menaxhimit të Qëndrueshëm të Resurseve të Agregateve (SARM-a), duke i paraprirë projektit Transnacional të Kooperim-fonde të SEE (http://www.sarma.eu). SNAP-SEE u financua nga EU South East Europë (SEE), Transnational Cooperation Programme (SNAP-SEE, SEE/D/0167/2.4/X) dhe ka 27 partnerë nga 12 vënde të Europes Juglindore (SEE) dhe nga Turqia. Universiteti i Leobenit, në Austri, ishte Partner Udhëheqës. SNAP-SEE ishte një projekt dy-vjeçar dhe mbaroi në Nëntor 2014.

SNAP-SEE Toolbox-i, për Planifikimin e Agregateve, përmbledh 4 produkte me lidhje të brëndëshme dhe që mbështesin reciprokisht njëra tjetrën.

\section{Një Vizion i Praktikave më të Mira për Planifikimin e Agregateve në Europën Juglin- dore}

Dokumenti i "Praktikave më të Mira" përbën një vision për një tranzicion tek planifikimi i qëndrueshëm, i integruar, i gjerë, në Eurpën Juglindore (SEE). Ai inkludon diskutime të objektivave të rëndësishme që duhet tu adresohet, hapat interim që mund të merren drejt një planifikimi më të qëndrueshëm, dhe një revizionim të komponentëve që duhet të përmbajë një plan i qëndrueshëm.

\section{Si të ndërtosh një Plan të Qëndrueshëm të Agregateve}

Ky document "si të", përbën një hartë të rrugëve për planifikim, përfshi diskutimet e vet procesit të planifikimit dhe hapat e tij të ndryshëm. Shëmbuj të shkruar mirë, të moduleve të planifikimit janë dhene gjithashtu. Ato shprehin principet, përafrimet dhe aksionet e domosdoshme, për të arritur objektivat e Vizionit, të marra në raportin e Praktikave më të Mira.

\section{Konsultimi i Grupeve të Interesit kur Aplikon Praktikat më të Mira në Planifikimin e Qëndrueshëm të Agregateve}

Dokumenti i "Konsultimit" jep hap pas hapi udhëzime se si të planifikosh dhe të drejtosh konsultimet e grupeve të interesit, kështu të sigurohesh se industria, shteti, organizatat jo-qeveritare, dhe shoqëria civile mund të japin kontribut dhe të marrin pjesë në procesin e planifikimit. Kapaciteti i materialeve të ndertimit, është dhënë gjithashtu. .

\section{Të dhëna dhe Analiza në Mbështetje të Praktikave më të Mira në Planifikimin e Qëndrueshëm të Agregateve}

Dokumenti diskuton tipet e ndryshme të të dhenave, që sjellin informacion esencial për të kaluarën, për proçesin e planifikimit. Të dhënat e përcaktimeve, domethënia, përvetësimi, struktura dhe nevojat, janë adresuar po këtu. Janë dhënë metodat për 
vlefshmërine dhe analizimin e të dhënave, përfshi përafrimin për parashikimin e kërkesave.

Project Coordinator

(Koordinator i Projektit)

Guenter Tiess

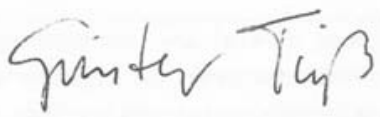

Montanuniversität Leoben

(University of Leoben) 


\section{Gjëndja e Planifikimit në SEE}

Sigurimi i qëndrueshëm, me burimet e agregateve është një ndërmarrje e rëndësishme, për nga mundësitë e kufizuara në rastin e qëllimit të një zhvillimi regjional të qëndrueshëm. Në sajë të diferencave regjionale dhe zhvillimit historik, $k a$ përafrime të ndryshme të politikave, planifikimit dhe menaxhimit të agregatve në Europën Juglindore, të cilat spostojnë efiçiencën e resurseve dhe zhvillimin ekonomik në rajon. Qëllimi i Projektit SNAP-SEE është të lehtësojë përmirësimin e planifikimit të agregateve në Europën Juglindore, për ta arritur këtë objektiv. 
Një nga karakteristikat bazë të planit egzistues mineral në EU është mospërputhja e disa politikave midis Autoriteteve të ndryshme, planeve të ndryshme sektoriale, dhe diferenca në nivelin e avancimit. Përafrimet diagramatike, që jepen më poshtë në këtë kapitull, duan të tërheqin vëmëndjen e autorëvet të inkluduar në proçedurat $\mathrm{e}$ planifikimit, në marrëdhëniet midis rangjeve legjislative dhe dokumenteve të autorizimit që ata lëshojnë. Ky përafrim komplementohet në analizat e dhëna nga Horváth et al. (2014) dhe nga Agioutantis et al. (2014), që të dy të inkluduar në këtë Toolbox.

Në shumicën e Vëndeve Anëtare, një Ligj Specifik Minerar mbulon shfytëzimin e mineraleve zotëruese. Shumë vënde të Europës Juglindore (SEE), kanë, gjithashtu, një politikë minerale. Politikat sektoriale janë deklaruar si objektiva qeveritare, duke nxitur rritje ekonomike, sociale dhe zakonisht, zhvillim ambjental të vendit. Politikat përcaktojnë strategjinë nacionale dhe janë ndjekur nga zhvillimi i planeve. Planifikimi, është kështu, krijimi i disa proçedurave formal, për tu ndjekur për realizimin e objektivave. Plani i administrimit përbën mandatin e personelit menaxhues.

Atje ku egziston një ligj minerar, adoptimi i politikave speciale dhe planeve nuk kanë përhapje, por zhvillimi i këtyre planeve, është një proçes në ecje. Kjo, është një mundësi e madhe për të adaptuar përafrime të qëndrueshme në rajon.

Një shëmbull i këtij proçesi në ecje, janë zhvillimet në Malin e Zi (Figura 1): Një Plan Hapësinor i Malit të Zi për periudhën deri në 2020 është dokument që vë fundamente jetëgjatë për organizimin dhe peisazhimin e vëndit deri në vitin 2020 . Plani Shtetëror është i përgjithshëm, por kur është fjala për resurset minerale, një ndër pikat e planit kërkon një vlerësim të resurseve minerale egzistuese në vend, një vlerësim të rezervave, lokalizimin e vëndburimeve minerale, si edhe lokalizimin/vëndin ku shfytëzimi është bërë shumë kohë më parë.

Në këtë vënd, planifikimi që u përket agregateve, mbulohet nga dy ligje të veçanta: Ligji për Koncesionet dhe Ligji Minerar. Më i rëndësishëm, për sa i përket planifikimit të agregateve, është Ligji Minerar, që përcakton detyrimin për të adoptuar një plan shtetëror për shfrytëzimin e resurseve minerale, i cili përmbledh një plan të përgjithshëm dhe një plan për shfrytëzimin e resurseve të mineraleve të veçanta. Gjithashtu, Ligji për Koncesionet, që është e vetmja rrugë për të marrë të drejtat për zbulimin dhe shfrytëzimin e resurseve minerale, janë realizuar në bazë të një plani afatgjatë të adoptuar nga Qeveria. Zbulimi dhe shfrytëzimi i resurseve minerale në Malin e Zi, janë subjekte të konçesioneve që $u$ jepen kompanive nga Shteti, mbi bazën e një plani vjetor të konçesioneve. Një plan vjetor është miratuar nga Qeveria e Malit të Zi, pas një dëgjimi public, të drejtuar nga Ministria e Ekonomisë, kur është fjala për gurin teknik të ndërtimit (gurin e thërmuar) dhe rërat e zhavorri, që nuk merren me karriera nga lumenjte, dhe nga Administrimi i Ujërave, kur është fjala për 
zhavorrin e lumenjve dhe vendburimet e rërës. Plani i konçesioneve, midis të tjerash , identifikon vëndin për të cilin jepet konçesioni.

Politika Nacionale e Menxhimit te Mbetjeve, Master Plani Strategjik i menxhimit të Mbetjeve, Studimi mbi revizionimin e vlerësimit te domosdoshmërisë së Masterplanit Strategjik të Menaxhimit të Mbetjeve, dhe rekomandimet për Organizatat e Ngarkuara me Menxhimin e Mbetjeve për një periudhë deri në vitin 2030, duhet gjithashtu të kihen parasysh. Ligji për Menxhimin e Mbetjeve përbën kornizën legjislative në zonën e menaxhimit të mbetjeve. Ligji, është miratuar në vitin 2011. Janë miratuar gjithashtu, disa legjislacione mbeshtetese.

Kështu, një plan integrimi, afatgjatë i resurseve të ndryshme të agregateve në të ardhmen, është i mundshëm, dhe legjislacioni që përcakton nevojat e menaxhimit të agregateve egzison, por për momentin Mali i Zi, nuk ka zhvilluar akoma një plan specific të agregateve. Planet kushtuar resurseve minerale, i pari midis tyre plani shtetëror për shfytëzimin e resurseve minerale, çon në efiçencën e resurseve dhe teoritikisht mund të jetë i krahasueshëm me objektivat e SARM dhe SSM.

\subsection{Planifikimi i agregateve parësore dhe dytësore}

Domosdoshmëria për të reduktuar përdorimin e resurseve natyrore të parinovueshme dhe, në të njëjtën kohë, për të minimizuar impaktet negative nga prodhimi dhe menaxhimi i mbetjeve te sektorit të ndërtimit, është rritur interesi për riciklimin e mbetjeve, veçanërisht në sajë të Komisionit Europian. Kështu, opsioni për të rikuperuar disa fraksione të mbetjeve dhe ti rifutësh ato në ciklet e prodhimit, në formën e produkteve ose si lëndë e parë, është konkretizuar.

Rezistenca kulturale në përdorimin e agregateve të ricikluara, nisur nga origjina e tyre e mbetjeve, është një ndër pengesat kryesore për zhvillimin e industrise ricikluese, të agregateve. Me qëllim që të eliminohet përfundimisht tek perdorusit mentaliteti i pa kuptimtë, është e domosdoshme, të proçedohet sipas Direktives 2008/98/EC, të përcaktohen sa më parë të jetë e mundur kriteret, sipas të cilave mbetjet kthehen në lëndë të dobishme (Bressi et al., 2011).

Pasi agregatet dytësore të kenë humbur statusin e tyre si "mbetje", ato mund të konsiderohen si një burim alternativ i materialeve për përdorime specifike. Në sajë të këtij "ndryshimi të statusit", edhe sot akoma, në shumë vënde të Europës Juglindore (SEE) politikat e agregateve parësore dhe dytësore si edhe planet nuk do të mbeten në të njëjtin dokument të perbashket. Ato, janë të shperndara në shumë dokumente të ndryshme legale, duke e bërë koordinimin dhe kuptimin e plotë të vështirë. Gjithashtu, është përhapur një mungesë koordinimi në planifikimin e furnizimit me agregate parësore dhe dytësore. 
Duke qenë se agregatet dytësore janë çelësi për të zëvëndësuar përdorimin e agregateve të pa rinovueshme dhe të reduktojë impaktet në ambjentin rrethues, autoritetet e planifikimit, duhet të identifikojnë volumet e resurseve dytësore që mund të përdoren si aggregate. Në veçanti, përdorimi i agregateve të ricikluara ka qënë rritur pasi një numur vëndesh $i$ kanë adoptuar

Shtetet e Europës Juglindore (SEE) janë në një proçes në vazhdim për të bërë inventarin e agregateve dytësore, ose së paku një rregjistër të burimeve potenciale të agregateve të tilla. Shumë shëmbuj egzistojnë, por per momentin, shumë nga dokumentet më të kompletuara të resurseve potenciale janë grumbulluar nga Provinca e Trentos (Figura 2) dhe nga Kroacia (Figura 3), që gjithashtu vlerësojnë të dhënat e kërkuara nga nxjerrja e agregagateve gjatë punimeve civile, sëbashku me mbetjet $\mathrm{C} \% \mathrm{D}$, nënproduktet e nxjerra dhe mbetjet industriale. Ndërsa Sllovenia (Figura 4), Sërbia, Sllovakia, dhe Auistria grumbullojnë përqindje nga sasia e produktit të agregateve dytësore të ricikluara.

\section{Shkurtimet e përdorura në skemat nacionale (Figurat 1-9):}

Inter. Com.: Komiteti ndërdisiplinor;

S.E.A.: Astetet Srtategjike, Ambjentale;

E.I.A.: Asetet e Impakteve Ambjentale;

M.I.E.: Ministria e Industrisë dhe Ekonomisë;

M.o.E: Ministria e Ekonomisë;

N.C.L.: Qëndra Nacionale e Liçenzimit;

Një version më i gjere i skemës, prezantohet në faqet e mëposhtme, në projektin SNAP-SEE: website www.snapsee.eu. 


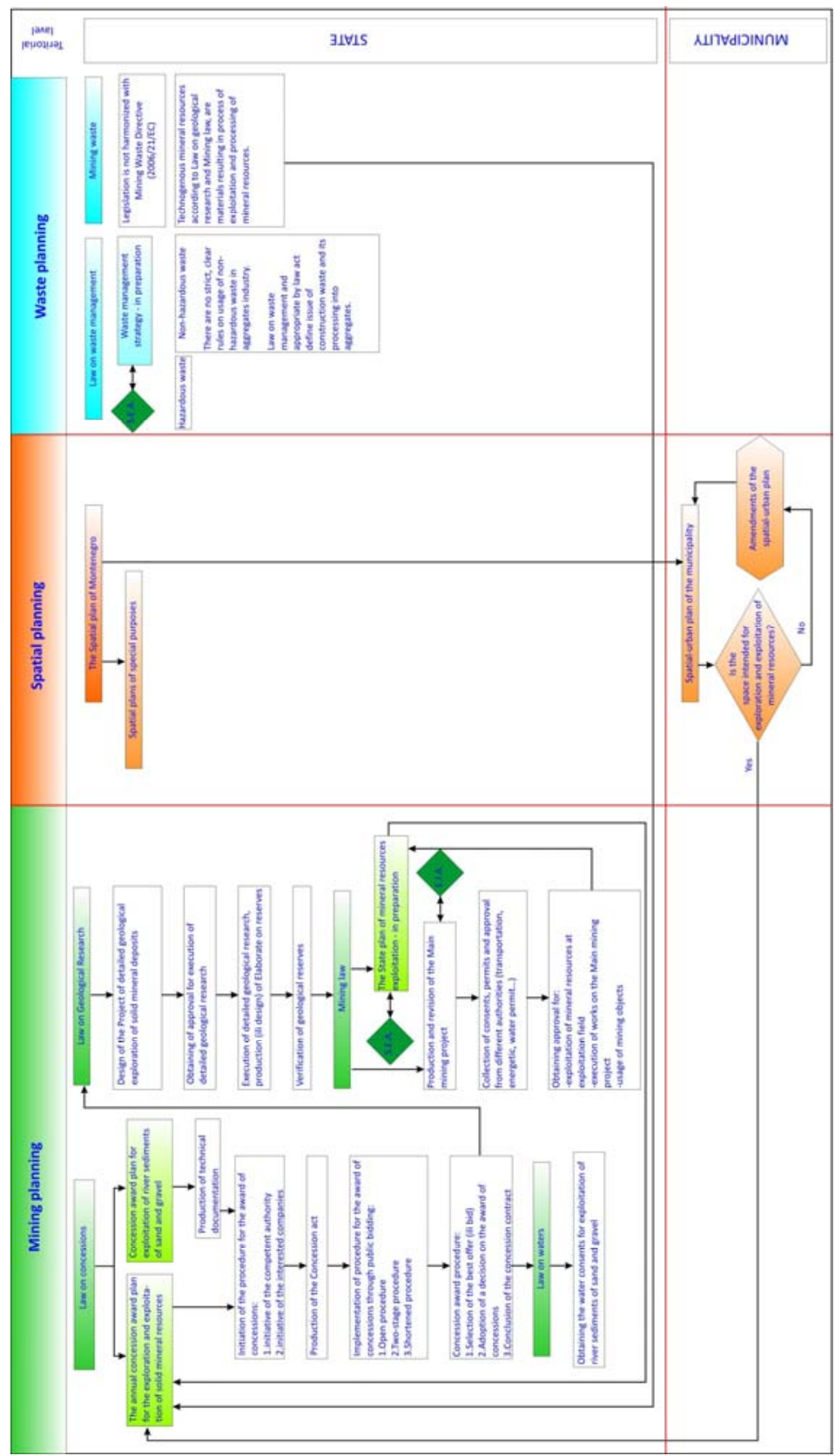

Figura 1 - Marrëdhëniet midis planifikimit hapësinor dhe proçedurave minerare në Malin e Zi. 


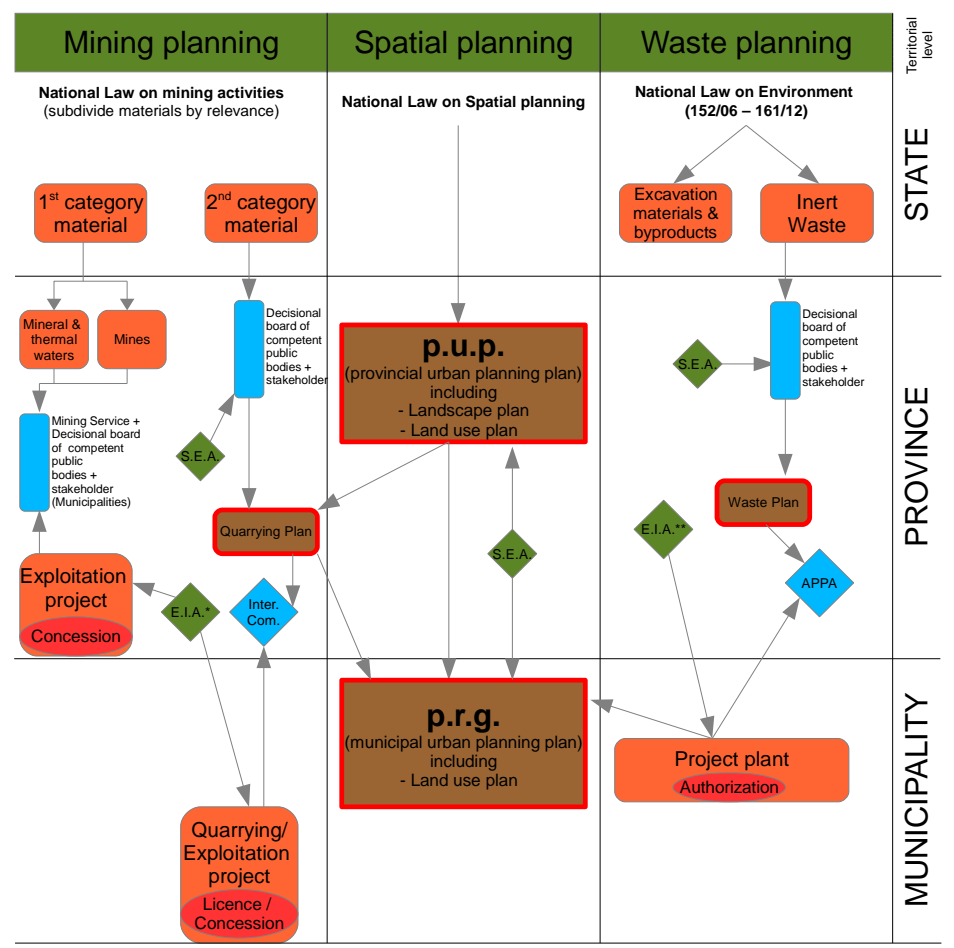

Figura 2 -Planifikimi hapësinor në provincën e Trentos, Itali:

Planifikimi minerar dhe procedurat e planifikimit hapësinor, janë të krahasueshme me ato të Provincës Emilia-Romana (shiko figuren 6), ndërsa një plan mbetjesh ka qënë adoptuar më herët. Një Komitet Ndër disiplinor është ngritur në Trento, aprovuar më ligjin provincial, duke vlerësuar të gjitha projektet e shfrytëzimit në provincë. Komiteti është thirrur nga Shërbimi Minerar dhe është i përberë nga APPA, Vlerësimi Ambjental, Shërbimi, Shërbimi i Pyjeve dhe Faunës, Shërbimi Gjeologjik, Shërbimi i Planifikimit Urban, dhe një Ekspert i Jashtem ( $\mathrm{i}$ zgjedhur nga shoqëria industriale). Ai verifikon projekte, nëpërmjet një opinioni të shpejt pozitiv ose negativ, dhe Bashkia ka detyrimin ti japi liçenzen ose konçesionin ne përputhje me këtë opinion. *: ligji provincial LP 28/1988 përcakton limitet, tej te cilave, një vlerësim i impaktit ambjental kërkohet të bëhet. Për shfrytëzimin e mbi $200000 \mathrm{~m}^{3}$ material, kërkohet një proçedurë mbrojtëse, ndryshe nga rasti i shfrytëzimit të $500000 \mathrm{~m}^{3}$ material (ose për sipërfaqe më shumë se 20 hektaresh), për të cilën kërkohet një E.I.A. **: Projekti është bërë subjekt i një E. I. A., i fokusuar më shumë në menaxhimin e mbetjeve (kriteret e lokalizimit, tipet e mbetjeve, trajtimi, barrierat zhurmuese dhe ato të pluhurit...). Shigjetat qe dalin nga fundi ne krye, tregojne se proçedurat për të marrë një liçenzë, një konçesion, ose një autorizim, fillon që nga kompanitë e karrjerave: Kërkesa duhet të jetë në përputhje me instrumentet e parashikuar në planet, dhe sëbashku me vetë planet (p.sh. lokalizimi). Bashkitë marrin kërkesat për karriera dhe i dërgojnë në Sherbimin Minerar, që therret Komitetin Ndërdisplinor. Për materialet e kategorisë së parë, kompanitë duhet të paraqesin projektet e tyre në nivel krahinor (Shërbimi Minerar), Bashkitë e interesuara janë të inkluduare në proçesin e vendimarrjes. 


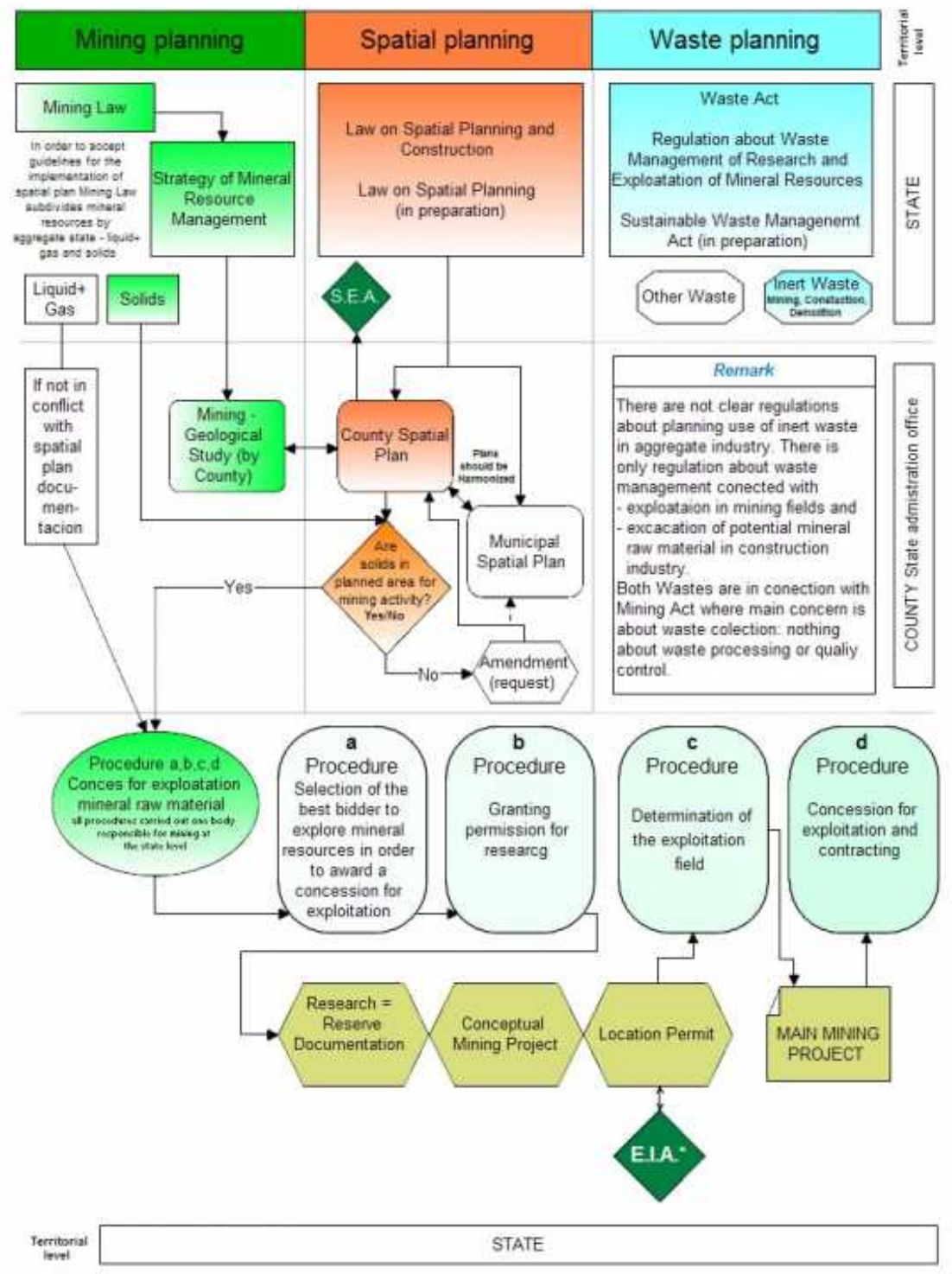

Figura 3 - Planifikimi hapësinor dhe ndërthurja e tij me ligjet minerare dhe akti i menaxhimit të mbetjeve në të ardhmen, në Kroaci. *: Vleresimi i Impakteve të Ambjentit në Kroaci është obligim për të gjitha operacionet në industrinë e minierave. 


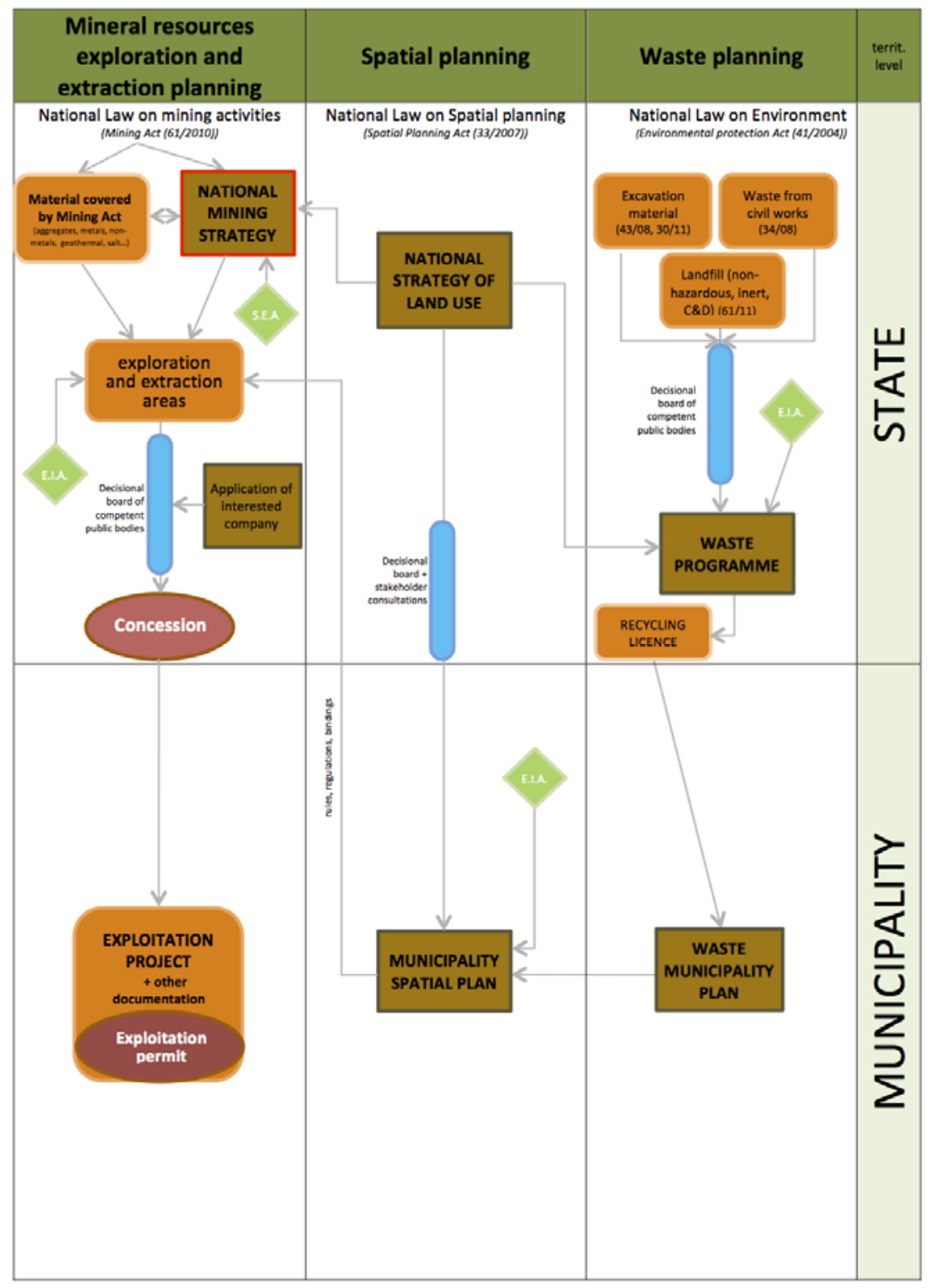

Figura 4 -Planifikimi për Agregatet e mbetjet dhe bashkeveprimi i tyre me planifikimin hapësinor, në Slloveni. 


\subsection{Nje përafrim i centralizuar apo një i decentralizuar?}

Eksperienca në Europën Juglindore, (SEE), tregon se shumë vënde i delegojnë implementimet e politikave të mineraleve te tyre, në rangje më të ulëta të qeverise. Në shumë vënde, bashkitë, luajnë një rol kyç në proçedurat e lejeve, megjithëse roli i tyre në planin e zhvillimit nuk është i qartë ose i papërcaktuar.

Shumë vënde, vazhdojnë një përafrim të centralizuar, p.sh. midis të tjerash, janë Shqipëria, Sllovenia, Sërbia. Një përafrim i centralizuar, ka shumë avantazhe, përfshi lehtësine e perpilimit të një strategjie nacionale koherente, pa risk, në mungesen e harmonizimit midis nivelit te dytë të personelit administrativ. Një avantazh tjetër, është zakonisht, pamjaftueshmëria e kompleksitetit në proçedurat e lejeve, që mund të bëhet nga një autoritet $\mathrm{i}$ vetëm.

Si shembull, në Shqipëri plani i aksionit për implementimin e strategjisë minerare është realizuar dhe është përshkruar në Ligjin Minerar Nacional (Figura 5). Plani i aksionit përcakton implementimin e strategjisë afatmesëm të një dokumenti planifikimi minerar, të përpiluar mbi bazën e strategjisë minerare dhe është i vlefshëm për një periudhë tre-vjecare. Ky plan aksioni përmbledh:

Drejtimet për zhvillimin e sektorit minerar;

Promocioni i sipërfaqeve minerare për të cilat liçenzat minerare do të jepen nëpërmjet një proçesi konkurues ose me proçedura të hapura;

Promocioni i sipërfaqeve minerare, bazuar në hartën minerare të dixhitalizuar, që është përpiluar brënda një viti nga hyrja në force e këtij ligji dhe që rifreskohet në mënyrë konstante;

Programimi i aktiviteteve bazë, studimore, gjeologjike;

Parashikimi i prodhimit vjetor total në sektorin minerar;

Kapaciteti i ndërtimit për aktivitete minerare;

Rregullat për implementimin e masave të sigurise dhe sigurimi i të punësuarve;

Rregullimi i mbrojtjes së ambjentit, peisazhimi dhe restaurimi;

Sipërfaqet me rreziqe, ku aktiviteti minerar dhe dhënia e të drejtave minerare është e ndaluar;

Tabelat me vlerat minimum të sipërfaqes së zonës së lejuar, vlera minimale e investimeve për lejen minerare të kerkimit dhe zbulimit, dhe vlerat minimale të prodhimit të mineralit të shfytëzuar për zonat e konkurimit dhe për ato hapura, në përputhje me grupin e mineraleve.

Në Shqipëri (Figura 5), seleksionimi i sipërfaqeve dhe kriteret për të përcaktuar për- 
masat minimum, vlerat e investimeve minimum, dhe vlerat minimum të prodhimit, është tërhequr mbrapsht nga Ministria dhe është aprovuar nga Këshilli i Ministrave. Kur implementohet programi i aksionit, plani vjetor minerar është adoptuar, i cili inkludon, përcaktimin e siperfaqes minerare gati të futet në të drejtën minerare për vitin respektiv. Plani vjetor është zhvilluar nga autoritete përgjegjëse për minierat dhe miratuar nga Ministri, nëpërmjet një proçesi konsultimi në nivelin qëndror (me ministritë perkatëse: Ministria e Ambjentit; Ministria e Turizmit; Ministia e Transportit; Ministria e Bujqësise; Ministria e Mbrojtjes), dhe në nivelin lokal me njisitë shtetërore dhe respektive, lokale. Ndonjë ndryshim apo shtojcë në planin vjetor aprovohet dhe publikohet me të njëjtën procedurë.

Një përafrim i centralizuar në shtetet e mëdha, mund të fshehë përfshirjen e komunitetit lokal gjatë zhvillimit të planit. Si shtesë, një përafrim i tillë duhet të merret, zakonisht, me diferenca sensible për përvetësimin e agregateve parësore dhe dytësore, dhe me një zhvillim më pak homogjen (dhe kështu, me tempe të ndryshme kërkese) në zona të ndryshme të vëndit. 


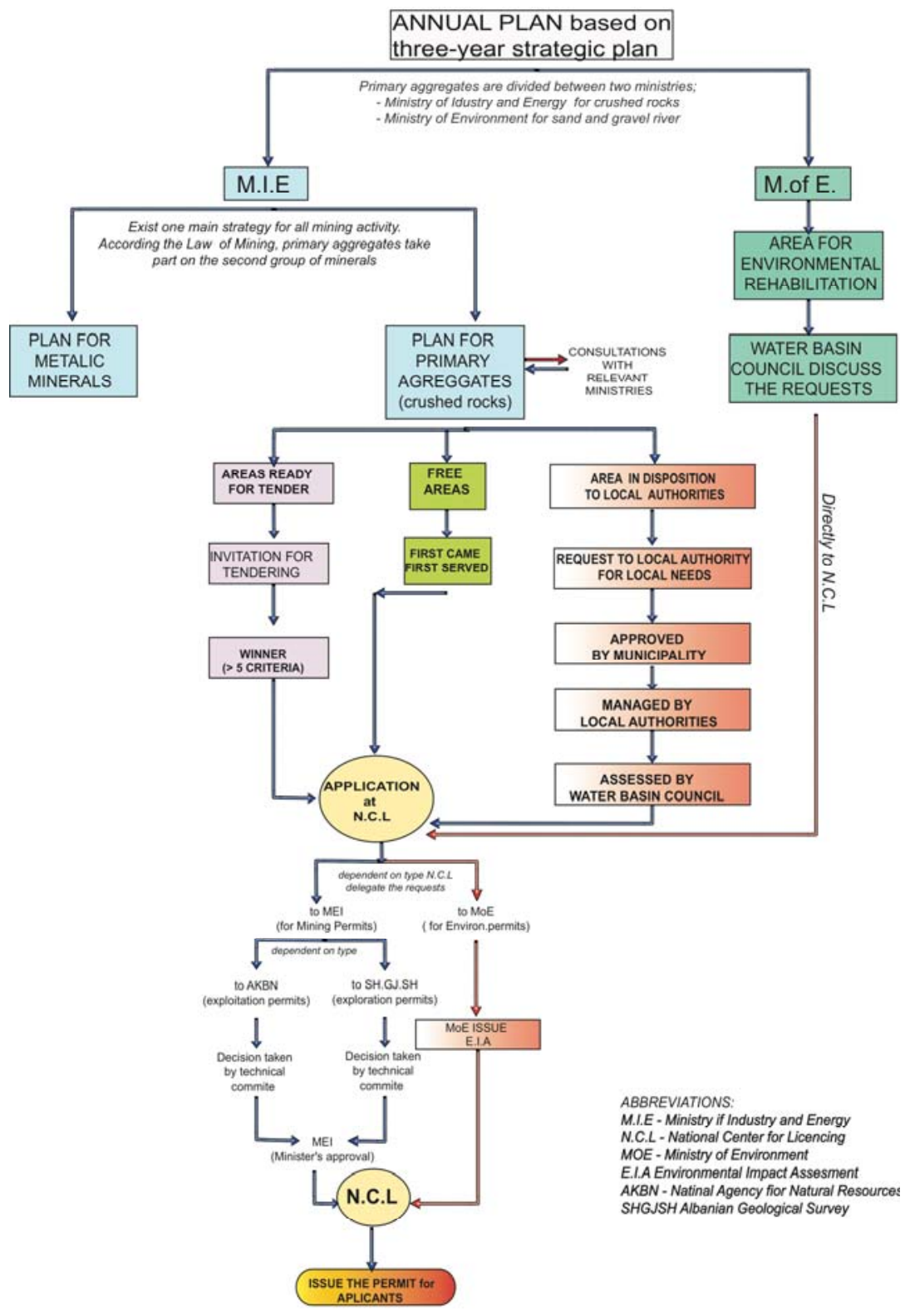

Figura 4 - Plani Minerar dhe proçedurat e lejeve në Shqiperi. AKBN: Agjensia Nacionale e Burimeve Natyrore, SHGJSH: Shërbimi Gjeologjik Shqiptar. 
Shtetet më të mëdha, kanë një kompleks më të madh marrëdhëniesh midis planeve nacionale dhe lokale: Shumë shëmbuj janë të gatshme për përdorim, si në Itali (Figura 6), në Greqi (Figura 7), Hungari (Figura 8), dhe në Austri. Në Itali, planifikimi i përdorimit të tokës $u$ është deleguar autoriteteve administrative të nivelit të parë (rajoneve); ato kanë aftësitë për të deleguar më tej disa nga funksionet administrative, të nivelit të dytë të autoriteteve administrative (provincave). Kjo është në rastin e Regjionit të Emilia-Romana, që në vitin 1991 delegoi zhvillimin e planeve minerare provincave të tij, nën frymën e një decentralizimi më të madh dhe një menaxhimi bashkëpunues të resurseve publike, duke ruajtur rolin qëndror koordinues. Plani minerar i provincës merr në konsideratë shumë pjesë të informacionit, rregullave, shtojcave, dhe rregullimeve që vijnë nga planet e tjera hapësinore, regjionale apo provinciale, si edhe të dhënat e resurseve. Regjioni sjell informacion mbi resurset gjeologjike, aprovon planin dhe mban një rregjistër të identifikimit të zonave të volitshme për gërmime.

Një bord vendimmarrës nga personeli publik, kopetent dhe nga grupe të interesit, drejtojnë proçesin që konturon planin minerar të Provincës (i përcaktuar gjenetikisht si plani i zgjeruar minerar), dhe një Vlerësues Strategjik Ambjental e verifikon atë. Plani minerar provincial përmban:

a) Një llogaritje sasiore në shkallë sug-regjionale të nevojave për materiale të ndryshme për një periudhë dhjetë vjeçare;

b) Një identifikim të poleve provinciale për shfytëzimin e agregateve dhe përcaktimin e kritereve dhe udhezimeve për lokalizimin e siperfaqeve minerare të rëndësisë provinciale, bazuar në resurset e përdorura (si përcaktohet në pikën (a) më siper), faktorët e natyrës dhe peisazheve, nevojat për tokat fermere dhe një pasqyrë e ujrave nëntokësore;

c) Kriteret dhe metodat për kultivim dhe rigjenerimin përfundimtar të karrjerave të reja, si edhe për rigjenerimin e karrjerave tashmë të abandonuara;

d) Kriteret për përdorimin e pas mbylljes dhe/ose restaurimin për përdorim natyral dhe publik.

Plani është i shoqëruar me një studim për balancin ambjental, që verifikon gjëndjen ambjentale të minierave, mbi bazën e legjislacionit aktual. Studimi i planshetit të balancës ambjentale, përmban identifikimin e sipërfaqes me sensibilitet më të madh ambjental, dhe arësyet për zgjedhjen e bërë, në krahasim me alternativat e mundshme, jepet gjithashtu në relacionin përkatës.

Plani minerar provincial ka një afat prej dhjetë vjetësh, pas të cilit ai duhet të rishikohet, të aktualizohet dhe të miratohet në nivel Bashkie, brënda dy vjetësh pas aprovimit. Planet minerare të bashkive përshkruajnë në detaje më të mëdha, kornizat e 
përcaktuara nga plani i Provincës. Këto plane, përfundimisht identifikojnë sipërfaqet potenciale të mundshme për shfrytëzim nga entet private; japin një vlerësim të impaktit ambjental, masat për reduktimin e impakteve të pritshme dhe planin e rikuperimit.

Rajoni ka rrol në gjetjen dhe rregullimin e krahasimit teknik të planit provincial për sipërfaqet e gjëra minerare, me planin provincial të përdorimit të tokës dhe me planet e rregullat regjionale, që eventualisht kërkojnë ndryshime specifike. Në mënyrë të ngjajshme, përgjegjësia publike në Austri, është e ndarë midis katër niveleve të shtetit në strukturën federale - Qeveria Federale, Shteti Federal (Länder), Distriktet dhe Bashkitë. Qeveria Federale, në mënyrë specifike, Ministria e Ekonomisë, Family and Youth, është përgjegjës për politikën e të gjitha materialeve si lëndë e parë, por planifikimi hapësinor, për përdorimin e tokës është përgjegjësi e shtetit federal.

Si rezultat, të nëntë shtetet federale kanë ligjet e tyre të planifikimit regjional, i cili në të kaluarën, i ka pas diferencuar provincat në lidhje me mbrojtjen e resurseve minerale. Pasi puna në Planin e Resurseve Minerale avancoi, dhe me asistencën e qeverisë federale, shumica e shteteve kanë bërë planet e tyre sektoriale të zhvillimit regjional për lëndët e para dhe kanë përcaktuar "zonat e mundshme" ose " zonat e sigurta minerale". Zhvillimet në nivelin e shtetit federal, duhet të llogarisin interesat lokale. Për më tepër, si rezultat i Vëndburimeve Minerale Akti 33 i vitit 1947, Shërbimi Gjeologjik dhe Autoritetet e Minierave, janë të detyruara të kooperojnë në kërkimin e territorit për minerale. Një kooperim afatgjatë dhe konstruktiv, i zhvilluar në bazë të kësaj kërkese, ka sjellë nje bazë të shkëlqyer për stabilizimin e një informacioni të kualitetit të lartë për mineralet aktuale.

Shembujt e dhënë demonstrojnë se si natyra e centralizuar e planit reflekton organizimin nacional të planifikimit hapësinor. Kjo eshtë e deshërueshme kur vëndi është më i vogël se $100,000 \mathrm{~km}^{2}$ dhe për deri sa ai lejon një revizionim komplet të të gjitha resurseve të agregateve dhe një parashikim më të mire të tyre. Ka shumë raste, sidoqoftë, ku bile edhe natyra e planit ka qënë tashmë e stabilizuar nga ligjet nacionale ose që një plan i nevojave të bëhet për një territor specifik, me qëllim të një fokusimi më të mirë mbi bazë të dokumenteve regjionale (si një shembull, ju lutem, krahasoni skemat e Bosnjës dhe Hercegovinës (Figura 9).

\subsection{Mbi kompleksitetin e ndërtimit të një plani për resurset minerale}

Planifikimi i resurseve të agregateve, zakonisht, është i inkluduar në një plan më të përgjithshëm të resurseve minerale. Plani i Resurseve Minerale të Austrisë, në një numur rastesh, është cituar si praktika më e mirë në planifikimin e përdorimit të tokës. Veçori të ndryshme të këtij plani, përfshi përafrimin e tij sistematik, përbëjnë një praktikë të mirë, dhe detalizime të mëtejshme, aktuale janë bërë, për implementimin e tij në nivel lokal (CSES, 2014). 


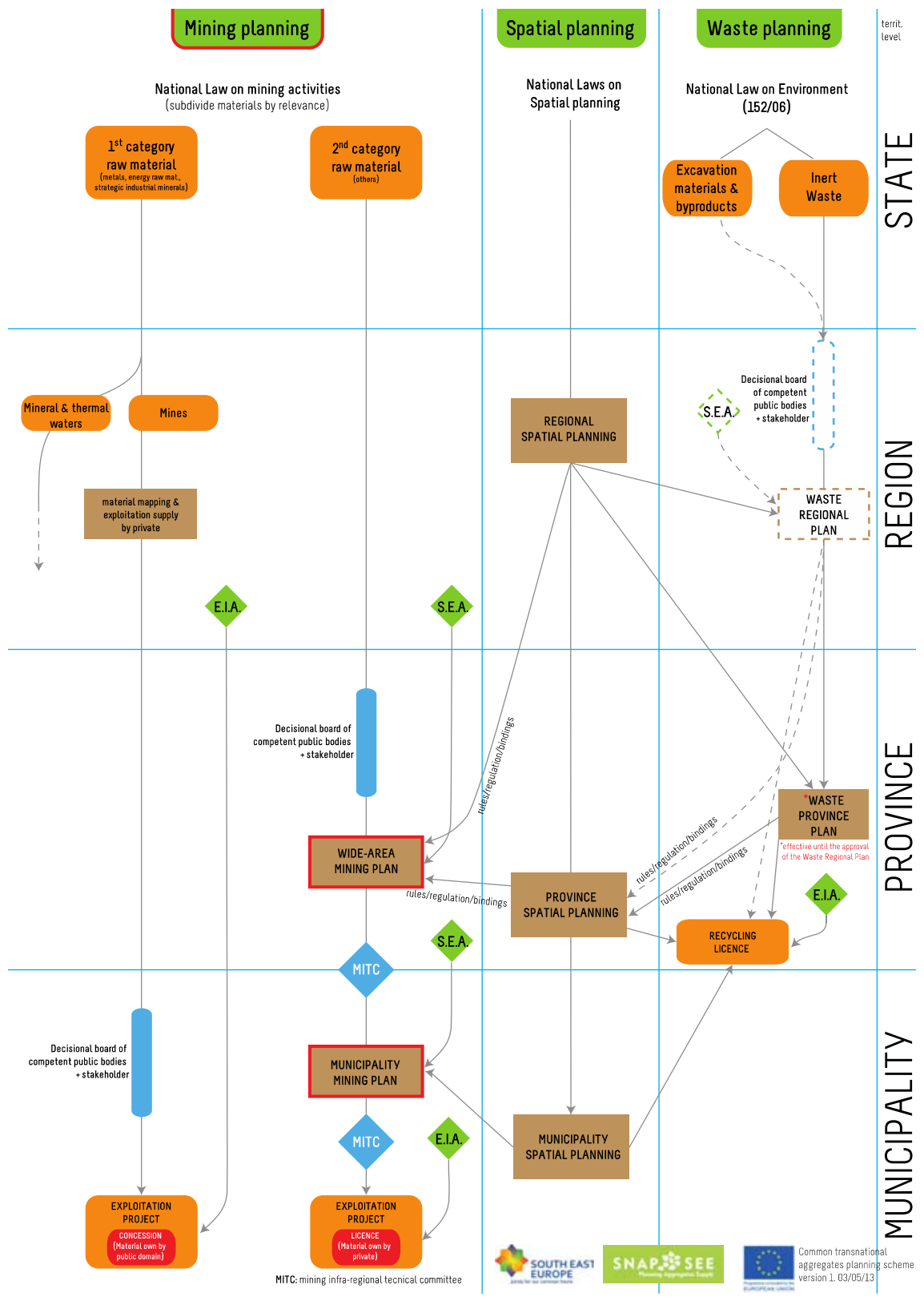

Figura 4 - Planifikimi Regjional për furnizimin me agregate: një shembull nga Rajoni EmiliaRomagna, në Itali. 


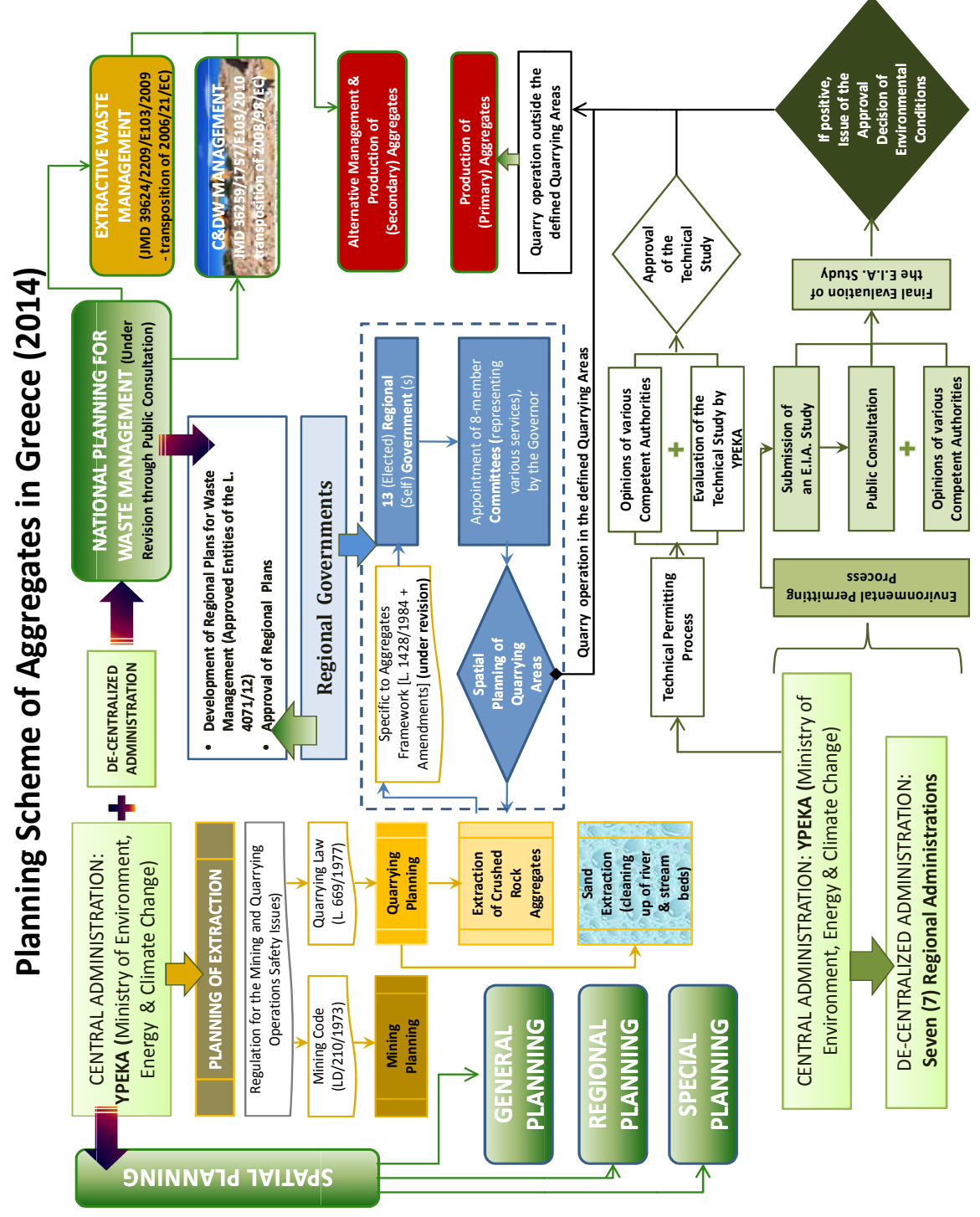

Figura 5 - Skema e Planifikimit të menaxhimit të Agregateve në Greqi. 


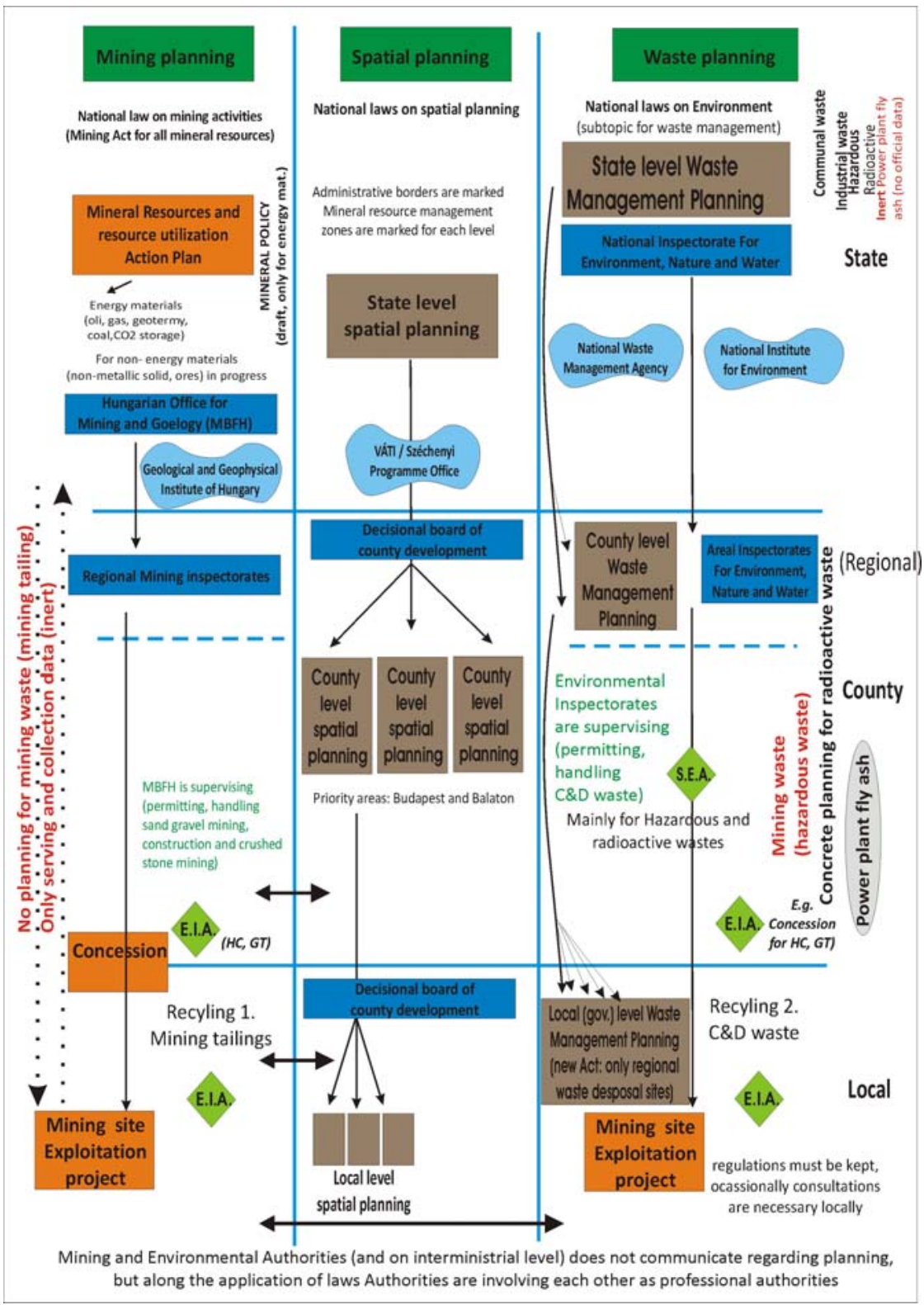

Figura 6 - Struktura minerare, planet e menaxhimit hapësinor dhe të mbetjeve në Hungari. 


\section{Aggregates planning scheme in Bosnia and Herzegovina and Herzegbosnian canton}

LEVEL

MINING PLANNING

STATE LEVEI

STATE LEVEL:
Bosnia \& Herzegovin
(B\&H)

$$
\text { L-1 }
$$

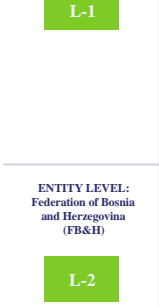

and

Law on mining \& Law on geological researches do not exist at athe state level (B\&H)

\begin{tabular}{c}
\hline ENTITY LEVEL: \\
Federation of Bosnia \\
and Herzegovina \\
(FB\&H)
\end{tabular}
Agency for Water

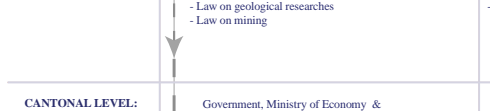

\begin{tabular}{c||c|c|c|}
$\begin{array}{c}\text { CANTONAL LEVEL: } \\
\text { Herzegbosnian canton } \\
\text { (HB Canton) }\end{array}$ & $\mid \begin{array}{c}\text { Government, Ministry of Economy \& } \\
\text { Commision for concessions of HB Canton }\end{array}$ \\
\hline & $\mid$
\end{tabular}

L-3
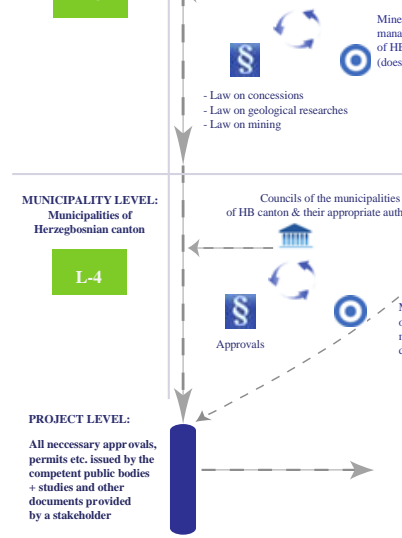

LEGEND
IIIIII
on certain administrative levels
Law, approvial, decision of other type of administrative acts of
certtain competent authorily

4 SOUTHEAST

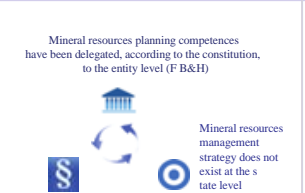

Government of F B\&H, Federal Ministry of Ener gy, Mining and Industry \& F F\&H COmmision for concessions,
Agency for Water Area of the Adriatic Sea

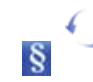
Mineral resources
management strategy
of $F$ B\&H in the next
(in prears
(in preparation)

Law on concessions - Law on geologic
- Law on mining

SPATIAL PLANNINC

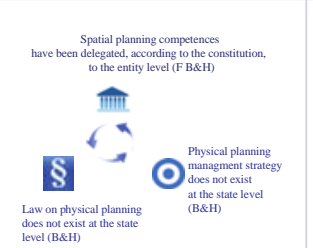

Government of F B\&H \&

Federal ministry of physical planning

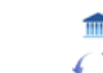

\section{s}

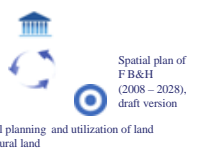

Law on physical planning
Law on agricultural land

Govemment, Ministry of construction, reconstruction, patial planning and environmental protection of $\mathrm{HB}$ canton <-

S $20 \begin{aligned} & \text { Mineral resources } \\ & \text { management strategy } \\ & \text { of HB canton } \\ & \text { (does not exist) }\end{aligned}$

Law on concessions - Law on mining

- Law on mini 
Leksioni i parë që mund të mesohet nga eksperienca Austriake është se zhvillimi i planit mund të kërkojë një kohë të gjatë, përderisa kërkohet një sintezë e kujdeshme dhe objektive e të dhënave për shfaqet minerale, një kartografim preciz i resurseve të arritshme dhe një analizë e konflikteve të tyre me strategjitë e tjera të përdorimit të tokës.

Si përafrim i parë, shfaqet e vlefshme minerale që duhet të mbrohen për cilesinë dhe sasinë e tyre, u identifikuan në siperfaqet me konflikt interesi. Këto shfaqe iu kaluan atëhere në kopetenca, autoriteteve të provincës, për ti deklaruar ato, si sipërfaqe në konservim të lëndëve të para, në planifikimin e përdorimit të tokës. Me respektimin e lëndëve të para, të konservuara në planifikimin e përdorimit të tokës, $u$ bë e mundur, që rëra dhe zhavorri u bënë të gatshme për përdorim për 50 vjet dhe guri $\mathrm{i}$ thërrmuar për më shumë se 100 vjet, për furnizimin e rajoneve më të shumta (Weber 2012).

Plani Mineral Austriak, mori të paktën dhjetë vjet për tu kompletuar. Ai filloi me një amendament në Aktin e Lëndëve të Para Minerale në 2001, dhe mbaroi në 2012 me publikimin e dokumentit (Weber 2012). Qëllimi i një plani, ishte të realizoheshin punimet paraprake, që kerkohen në pregatitjen e aktiviteteve nga ndërmarrjet private.

\subsection{Strategjia e Komunitetit Europian (KE)}

Studimet dhe debatet e nxitura nga SARMa dhe projektet SNAP-SEE, kanë lartësuar proçesin, se si zhvillimi i politikave nacionale mund të çojë tek disagregimi dhe johomogjeniteti, duke çuar tek dokumentet nderkufitare, ne sajë të kornizave të ndryshme legjislative. Edhe në ditet e sotme, ka akoma shumë diferenca midis politikave minerale dhe planeve në shkallë të ndryshme politike, brënda dhe më tej rajonit. Unioni Europian duhet progresisvisht, te integrojë dhe homogjenizojë politikat nacionale dhe planet, nëpërmjet përcaktimit të strategjive të përgjithshme. Vlereson të theksohet, se resurset e agregateve, duke qënë se konsiderohen një ndër lëndët e para që duhet të ruhen për gjeneratat e ardhshme, janë inkluduar në "Europe 2020 Strategy".

Pamvarësisht faktit, se jo të gjitha vëndet e Europës Juglindore (SEE) janë pjesë Unionit Europian (EU), principet e paraqitura nga strategjia EU2020, piketat mbi efiçiencën e resurseve, janë një objektiv mandator për të gjithë rajonin, në sajë të natyrës jorinovuese të resurseve të agregateve parësore dhe për arësye të impakteve që gërmimet dhe mbetjet inerte kanë në ambjentin rrethues dhe në shoqëri. 


\section{Një Hartë e Rrugëve për planifikim}

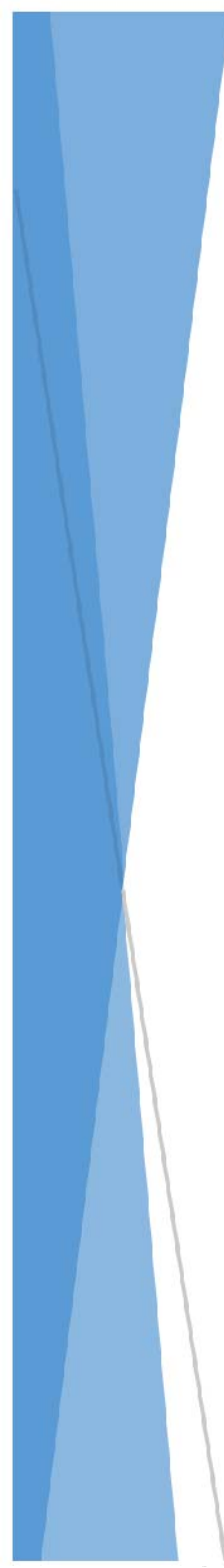

Zhvillimi i një plani duhet të filloje nga një strategji e nivelit nacional dhe duhet të ndjek oblikimet e përcaktuara nga ligjet nacionale.

Proçedura për pregatitjen e planit është zakonisht $e$ besueshme të adoptohet, me qellim që ajo të pranohet në seicilin sector specifik. Shfrytëzimi i resurseve minerale, përfshi agregatet natyrale, mund të gjenerojë impakte në tokë, dhe kërkohet një përfshirje e balancuar e grupeve të interesit, me qëllim që të nënvizohen nevojat dhe përfitimet $e$ një përafrimi të qëndrueshëm. Zhvillimi i një plani strategjik, kërkon konsiderate dhe artikulim te vlerave dhe prioriteteve; plani duhet të reflektojë pikpamjet e shprehura nga të gjithë ata që janë përfshire në proçess. Shtetet që kanë përvijëzuar dhe adoptuar planet, kanë inkluduar të gjithë të interesuarit në proçesin strategjik të planifikimit. 


\subsection{Fazat e zhvillimit të planit}

\subsubsection{Faza e parë: Dokumenti paraparak}

Hapi i parë, në zhvillimin e një plani është e nevojshme, të analizohet rroli i entitetit në ngarkesën gjatë zhvillimit të planit, dhe objektivat e tij (Figura 10). Me qëllim që ti përgjigjet pyetjes " me ç'farë ne duhet të punojmë", duhet të përcaktohen forcat dhe dobësitë e entitetit të ngarkuar të planifikimit të agregateve, me objektiv të rritjes së forcave. Një lexim i dobishëm, për këtë pikë, mund të jetë "The special characteristics of aggregates planning" në librin Horváth et al. (2014), section 1.2.

Hapi i dytë, është të përcaktohet një vizion. Horváth et al. (2014), në mënyrë specifike e adresojnë këtë aspekt në pjesën e $4-^{\text {të }}$ të librit "Joint Vision on the Optimal Contents of Aggregates Plans" , duke dhënë një shëmbëll të mirë të vizionit në nivelin e vëndeve të Europës Juglindore (SEE), që ndoshta, adoptohet në nivel nacional. Meqënëse stema e vizionit të artikuluar nga vlerat e të inkluduarve në proçes, është esenciale, ky hap përmbledh të gjithë ata që do të kenë një risk në arritjen e vizionit.

Hapi i tertë, përmbledh artikulimin e objektivave, të identifikuara nga vizioni. Objektivat, mund të jenë të shumta dhe konfliktuale, si rritja ekonomike, furnizimi i bollshem me resurse dhe mbrojtja e ambjentit. Për çdo objektiv, planifikuesit mund të adresojnë menyrat për arritjen e objektivave të tyre. Ky hap, përmbledh strategjitë e artikuluara për arritjen e rezultatit. Strategjitë duhet të reflektojnë forcat dhe dobesitë e entitetit të angazhuar në planifikim, me qëllim që të mos kenë limit, p.sh.nga mungesa e të dhënave ose nga kapaciteti për të implementuar planin në të ardhmen.

Hapi i katërtë, duhet të fokusohet në përcaktimin e një kornize të njohurive, për të mbështetur strategjitë e identifikuara në hapin e tretë. Të dhënat janë një element esencial, për të siguruar një plan të qëndrueshëm. Pa të dhëna, nuk mund të bëhen parashikime dhe nuk mund të përshtaten ndryshimet me kerkesat. Ne se të dhënat nuk mblidhen në mënyrë të rregulltë, si duhet, edhe plani duhet të vleresohet për nevojën e këtyre të dhënave. Për deri sa një plan duhet të përcaktojë disa metoda, për të matur arritjet e objektivave, të dhënat përbëjnë gjithashtu një aspekt fundamental të monitorimit dhe vlerësimit të skenareve alternative. Për përmbledhjen komplet në këtë hap, përfshi përceptimet për analizën e ciklit të jetës si instrument për vlerësimin e skenarit potencial, ne ftojmë lexuesin të lexojë Agioutantis et al. (2014), inkluduar në këtë toolbox. 


\subsubsection{Faza e dytë: Shkëmbimi i informacionit}

Inkludimi i grupeve të interesit, duhet keshtu, të ketë vënd qysh në fazat e hershme të planit të zhvillimit (Figura 11). Udhëzimi, se si të organizohet inkludimi i grupeve të interesit, është dhënë nga Dolinar et al. (2014), inkluduar në këtë toolbox. Grupet e interesit duhet të edukohen, dhe të trajnohen për tu marrë me marrëdhëniet komplekse midis aspekteve natyrore, ekonomike, dhe sociale përsa i perket furnizimit me agregate parësore dhe dytësore. Për këtë arësye, është e rëndësishme të mbahen metingje dhe uorkshope, me qëllim që të pregatiten grupet e interesit për këtë subjekt.

Plani, duhet të zhvillohet nëpërmjet një proçesi interaktiv, me qëllim për të zgjidhur konfliktet eventuale midis aktorëve dhe objektivave. Një hierarki e objektivave, mund të ndihmoje në këtë rast, po ashtu si edhe një list e tyre, shumë e qartë dhe e shkurtër, me qëllim që të mos mbulohen agjensitë, si edhe industria me shumë detaje me të dhenat e grumbulluara dhe me raportimet.

Zyrtarët shtetëror dhe menaxheret e programeve publike, shpesh përballen në këtë pikë, me nevojën e bisedimeve midis mandateve në konflikt dhe objektivave, kur artikulojnë planet strategjike. Në këto raste, legjislacioni mund të draftohet me të dhënat e pjesëmarrësve të shumtë me pikpamje konfliktuese. Meqënëse menaxheret publik zhvillojnë planet strategjike, ata duhet të dinë, që këto programe, mund të kenë mandate të konfliktuara dhe të thjeshtojnë atë, ç'farë agjensia mundet apo nuk mundet të bëjë nën dritën e mandateve.

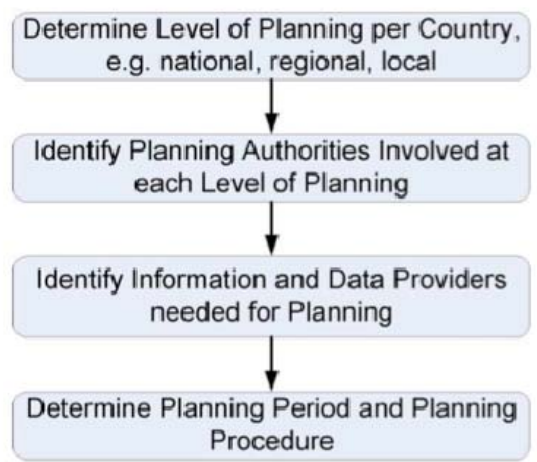

Figura 10 - Hapat e parë në zhvillimin e një plani minerar, sipas Agioutantis et al. (2014). 


\subsubsection{Faza e tretë: Aprovimi}

Pasi të jetë kompletuar konsultimi i grupeve të interesit, dokumenti i planit, duhet të finalizohet. Autoritetet e emëruara, të ngarkuara me zhvillimin e planit, duhet të marrin parasysh, sugjerimet dhe strategjite për zgjidhjen e konflikteve të mbartura nga faza e mëparshme. Dokumenti final duhet të detalizojë të gjitha aspektet e proçedurave të lejes, bashkëveprimin midis planit nacional/regjional dhe planeve të nivelit bashkiak, dhe të jap direktivat per të monitoruar rezultatet e vet planit.

Dukumenti final i pregatitur, duhet më pas, tu dërgohet të gjithë grupeve të inkluduara të interesit, për vërejtjet përfundimtare, që mund të pranohen apo të refuzohen, në përputhje me strategjite e skicuara, dhe më në fund, dërgohet në bordin politik për pranim dhe për ta bërë të njohur.

Plani minerar i përfunduar, duhet të reçenzohet e rifreskohet, dhe duhet të pranohet nga një bord i gjerë i grupeve të interesit. 

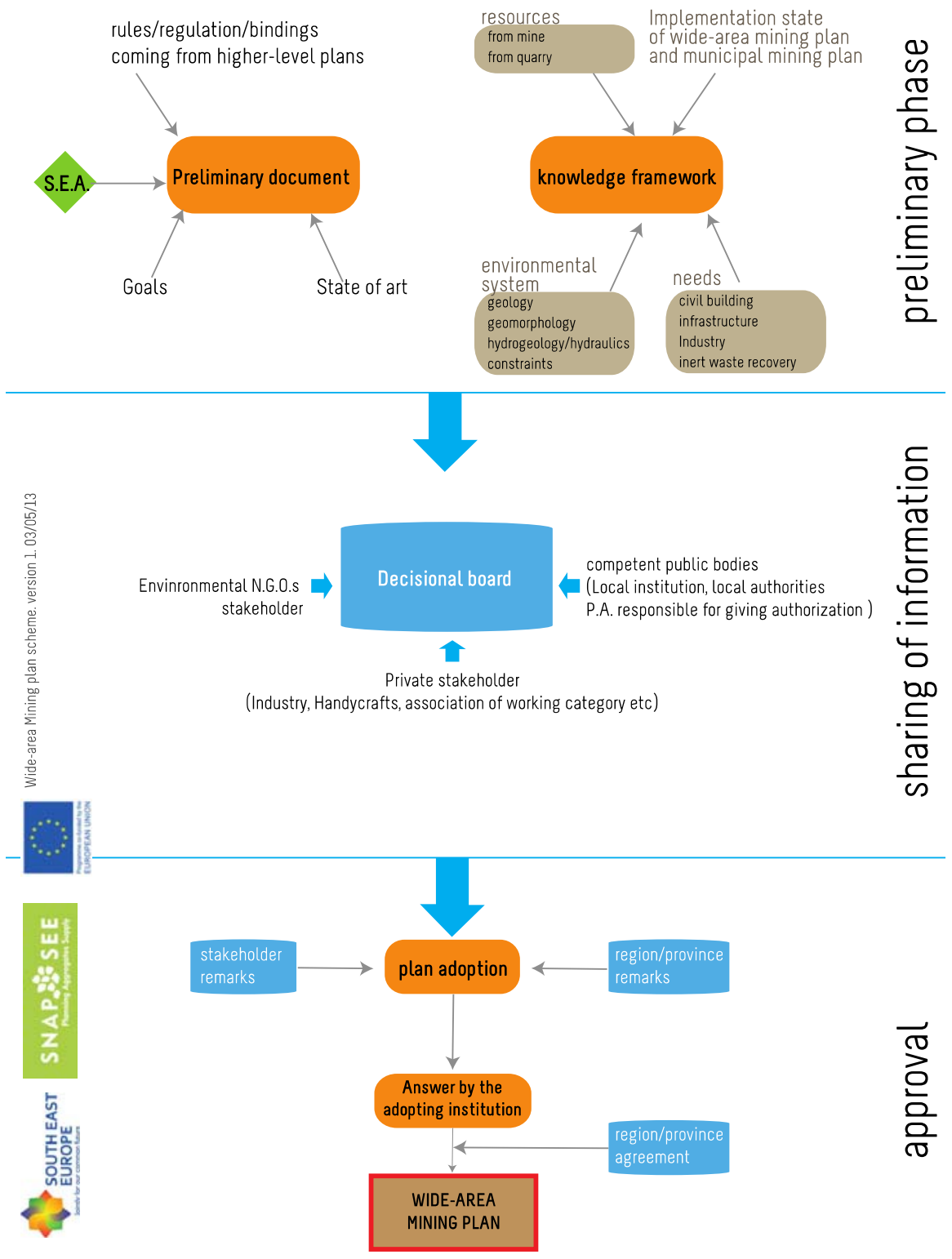

Figura 11 - Nje harte rrugore per planifikimin 


\subsection{Struktura e planit}

Proçesi i zhvillimit të planit, duhet të rregullohet nga ligjet nacionale.

Në se nuk specifikohet në ligjet egzistuese, atëhere një dekret që do ti jepte vlera planit do të duhej të paktën, të kishte:

Të ngresh nevojën e një plani (nacional) për resurset e agregateve;

- Të ngresh nevojën për ta integruar planin e agregateve në një plan më të përgjithshëm tëperdorimit të tokës.;

- Të koordinosh planin e agregateve me atë të menxhimit të mbetjeve;

- Të vendosësh pronësinë e agregateve parësore.

Proçesi që devijon planin duhet të drejtohet nga një bord vendimmarrës i autoriteve kopetente, publike dhe nga grupet e interesit, dhe duhet të verifikohet nga një Akt ligjor Strategjik, Ambjental.

Me qëllim që të jap një përafrim të qëndrueshëm, plani duhet të inkludojë:

- Një koherencë të brëndshme me principet e pranuara në nivel Europian, me qëllim që të sigurojë një homogjenizim progresiv të të gjithë rajonit;

- Sasinë e nevojave për materiale të ndryshme, për një periudhe të gjatë (në mënyrë ideale më shumë se 10 vjet);

- Një identifikim të siperfaqeve optimale, për shfrytëzimin dhe mbrojtjen e agregateve;

- Një identifikim të burimeve alterrnative, vlerësimin e kontributit të tyre për të reduktuar konsumin e resurseve natyrale dhe lokalizimin e tyre me qëllim që të reduktohen kostot e transportit dhe impaktet.;

- Percaktimin e kritereve dhe udhëzimeve për lokalizimin e sipërfaqeve minerare të rendësisë bashkiake;

- Një garanci mbi konkurueshmërine e industrisë së agregateve;

- Kriteret dhe metodat për kultivimin e BATs (Best Available Technologies), restaurimi final i karrjerave të lejuara rishtaz dhe restaurimi i karrierave të abandonuara;

- Kriteret për përdorimin pas mbylljes të tokes së karrjerave, përfshi, atje ku është e mundur, restaurimin në gjëndje natyrale/ose për përdorim publik; 
- Vendosja e sistemit koordinues midis autoriteteve lejuese dhe menaxhimit të planit të perdorimit të tokës;

- Vendosja e proçedurave efiçiente dhe efektive të dhënies së lejeve;

- Një studim, të balancimit ambjental, që verifikon bashkëegzistencen ambjentale minerare, mbi bazën e legjislacionit aktual.

Në faqet e mëposhtme, çdo pikë do të diskutohet në detaje dhe do të jepen shëmbuj të moduleve të tekstit. Qllimi i tekstit të moduleve,, është për të dhënë fjalorin, që mund të përdoret egzaktërisht nga autoritetet, meqënse ato zhvillojnë ose revizionojnë planet e agregateve. Teksti përbën një sintezë të përsëritjeve të lehta nga fjalori i praktikave më të mira të planifikimit, të përdorura në planet e ndryshme të agregateve brënda dhe jashtë Europës. Për seicilin element komplet dhe racional, ndoshta është e dobishme të integrohemi ne, duke lexuar rezultatet e paraqitura në Horváth et al. (2014), respektivisht tek "Vision of Best Practices for Aggregates Planning in South East Europe".

\subsubsection{Përcaktimi i nevojave të një plani nacional për resurset e agregateve}

Një plan nacional për resurset e agregateve, është i domosdoshëm, me qëllim të sigurimit të furnizimit të qëndrueshëm me agregate, në gjenerata.

Një politikë nacionale, minerale (agregate), mund të përcaktohet si të gjitha operacionet e një shteti për përballimin e furnizimit dhe nevojën për resurse minerale në territorin e vet.

Një Politikë Nacionale e Mineraleve, ka nevojë fillimisht, të zhvillojë njohuritë e nevojave të shoqërisë për minerale, dhe në mënyrë specifike për agregate, dhe në rastin e agregateve, të nevojave për akses në resurset lokale. Dokumenti i dytë, realisht shumë i rëndësishëm është, se ai duhet të vendosë furnizimin e mineraleve, dhe në menyrë specifike të agregateve, si një forcë për mirëqënien e shoqërisë, si edhe të vendosë një përafrim të balancuar në vlerësimin e shfrytëzimit dhe zhvillimit të aktiviteteve nxjerrëse (Tiess 2010, UEPG 2010).

- Në seicilin vënd, duhet të egzistojnë së paku, dy nivele planifikimi. Niveli më i lartë, quhet në kete rast, "Plani Nacional", duke iu referuar një plani, që mbulon aktivitetet në një sipërfaqe, të paktën 20-24 mijë km2, ose me një popullsi prej 2-5 milionë banorë. Një nivel i dytë i planifikimit, zakonisht, është në rangun e një bashkie, dhe kërkohet të sigurojë përdorim optimal të tokës, dhe pranimin e shoqërisë. Ai duhet ti referohet një plani më të përgjgithshëm, me qëllim që të sigurojë qëndrueshmërinë nacionale të furnizimit me resurset e agregateve. 
- Plani i resurseve të agregateve mund të jetë pjesë e një plani më të përgjgithshëm të resurseve minerale.

\subsubsection{Integrimi i planit të agregateve në një plan më të përgjithshëm të për- dorimit të tokës}

Fiksimi i planit mineral dhe i planit të resurseve të agregateve, në një plan më të përgjithshëm të përdorimit të tokës, bëhet me qëllim, për të siguruar akses në resurset e agregateve, bile edhe kur mund të ketë përdorues konkurrent. Kjo kërkesë, duhet të plotësohet drejt për drejt nga legjislacioni i përdorimit të tokës, dhe e trashëguar nga plani mineral.

\subsubsection{Vendosje e pronësisë të agregateteve parësore}

Pronësia mbi agregatet parësore në vëndet e Europës Juglindore (SEE) i përket në disa raste shtetit, dhe në vënde të tjera zotëruesve të tokës. Sidoqoftë, një furnizim mineral i sigurtë dhe i mjaftueshëm, është detyrë thelbësore e industrisë nxjerrëse, pamvarësisht se disa përdorues privat (jo për qëllime komerciale) janë lejuar shpesh.

Për të siguruar të drejtën minerare dhe kështu, të lejosh një plan të njohë lehtë zonën e mundshme të shfrytëzimit, pronari i agreagteve parësore, duhet ti përkas shtetit, ose të deleguarve të tij (Hamor, 2012). Duhet theksuar, sidoqoftë, se nuk është e mundur të detyrosh forcërisht një vënd, të ndryshojë rregullin, me qëllim për të transferuar zotërimin e pronës nga zotëruesi i tokës tek shteti, përderisa pronari $i$ pasurive të sigurta (përfshi agregatet), mbetet në legjislacionin suprem, nacional dhe nuk mund të ndryshohet nga plani sektorial (ose nga një ligj i EU).

Kur zotëruesi i agregateve nuk është njohur nga pronari i tokës, duhet të kërkohet një autorizim specifik, me qëllim që të gërmohet, dhe proçesi i autorizimit duhet të respektojë sipërfaqet prioritare të identifikuara nga plani.

\section{Shëmbull teksti modul 1:}

Pronari origjinal i resurseve të agregateve parësore i përket pushtetit lokal (shtetit, rajonit, provincës, prefekturës, bashkisë). Aktorët privat mund të konkurojnë, nëpërmjet prokurimit publik me qëllim që të jenë të garantuar për liçenzën, për të shfytëzuar në sipërfaqen e identifikuar. 


\section{Shëmbull tekst modul 2:}

Pronari origjinal i resurseve të agreagteve parësore i përket zotëruesit të tokës, përderisa agregatet parësore, janë klasifikuar si material karrjere. Me qellim që të lejohet shfrytëzimi i agregateve parësore, zotëruesi duhet të kërkojë një autorizim special për të balancuar nevojat e prodhimit me ato të ambjentit. Kjo kërkesë aplikohet në të dy rastet, si në rastin e pronarit të tokës që dëshëron të nxjerrë personalisht, një sasi materiali nga karrjera e ardhshme, po ashtu edhe në rastin e një sipërfaqeje të dhënë me qira tek një i tretë për shfrytëzimin e resurseve.

\subsubsection{Referenca tek principet e miratuara në një nivel Europian}

Proçedurat, për përcaktimin e planit sektorial, reflektojnë para së gjithash, kornizën legjislative të vëndit.

Me gjithë respektin për autonominë nacionale dhe arësyet historike që çuan në përafrime dhe në zhvillime të ndryshme në politikat e zhvillimit mineral në vëndet e Europës Juglindore (SEE), por e ardhmja e planeve për menaxhimin e qëndrueshëm të agregateve, duhet të llogarisë dhe të marrë drejtimin drejt strategjisë EU2020, për deri sa objektivat kryesore të saj mund të konsiderohen si emërimi minimum i përgjithshëm midis objektivave të një zhvillimi të qëndrueshëm.

Në shumë vënde të EU, autoritet regjionale apo lokale, janë përgjegjëse, për politikat e zonave të lidhura me strategjinë Europë 2020. Eshtë e rëndesishme që të gjitha nivelet e qeverisjes, të jenë të gatshme të implementojnë me efektivitet strategjinë "Europ ë 2020" mbi tokën, për të arritur kështu një rritje ekonomike të qëndrueshme, dhe që seicili, të luaj pjesën e tij në prezantimin e ndryshimeve të domosdoshme.

\section{Rregullore të EU, që duhet të merren parasysh:}

- Direktiva Kornize e Mbetjeve 2008/98/EC dhe vendimet e tij për implemintimin e vendimeve të Komisionit.

- Direktiva 89/106/EEC për afrimin e ligjeve, rregulloreve dhe parashikimeve administrative të Vëndeve Anëtare, në lidhje me produktet e konstruksioneve (amenduar nga Directiva 93/68/EEC)

- Kominikimi i Komisionit në kuadër të implementimit të Direktivës 89/106/EEC (2010/C 167/01) listat 11, standarte të ndryshme CEN me vështrimin nga agregatet.

- Katalogu Europian i Mbetjeve.

- Regullat e Gjykates së Drejtësisë (C-114 Avesta case) 
- Seveso II Directive amended

- Environmental Liability Directive (2004/35/EC)

- Mbetjet Minerare BAT Reference Document under IPPC Directive (BREF)

- EU Registri i Ndotjeve, Direktiva e Mbetjeve Minerare.

\subsubsection{Parashikimi i kërkesave për agregate në të ardhmen}

Eshtë e rëndësishme, të bëhet kërkesa dhe furnizimi afatshkurtër, afatmesëm dhe afatgjatë me agregate (d.m.th. parashikimi), një skenar në rajonet e rëndësishme, duke llogaritur furnizimin potencial në të ardhemen, përfshi resurset parësore dhe dytësore. Bazuar në skenare të tillë nevojash dhe furnizimi, konceptet e furnizimit me agregate dhe ato të përdorimit të tokës, do të mund të zhvilloheshin (përfshi analizën rrjedhjes së materialit për aplikimin e nevojave të ndryshme).

Një parashikim i kërkesave, mund të bazohet mbi gjykimin ekspert ose në modelin kuantitativ të disa formulareve. Seicili model do të ketë nivelin e tij të kompleksitetit dhe detajeve, duke nënvizuar teorinë, the metodën e implementimit. Ato që janë bazuar në karakteristikat sektoriale, janë fiksuar si modele me fundin lart; ndërsa ato që bazohen në intensitetin e përdorimit janë quajtur modele me majën poshtë. Modelet sektoriale, në mënyre tipike prezantojnë, ose një marrëdhënie rastësore, hipotetike, ose janë një tendencë ekstrapolimi i serieve, të vrojtimeve të grumbulluara në kohë, dmth të dhëna seriale kohore. Të mëparshmet janë modeluar me një, ose një fillim, si ekuacione regresioni ekonometrike, që besojnë varësinë e kërkeseave, në një ose më shumë variable spjegues indipendent, p.sh.aktiviteti ekonomik ose popullsia. Të mëvonshmet besojnë se modeli i kërkesave të kaluara do të vazhdojë në të ardhmen (Agioutantis et al., 2014).

\section{Tekst shëmbull:}

Plani vlerëson nevojat e një lënde të parë, dhe duke patur egzaminuar opsione të ndryshme, që janë të mundshme, ai identifikon sipërfaqet e preferuara të punës, të cilat do ti plotësojnë këto nevoja. Parashikimi i kërkesave të mundshme të së ardhmes, për minerale, duhet të informojë për vlerat e nevojave të ngjashme.

\subsubsection{Identifikimi i prioriteve dhe zonave të mbrojtura}

Sipërfaqet minerale, me vlera për tu mbrojtur, janë sipërfaqet minerale që nuk kanë ose kanë minimum konflikti me planet e tjera të perdorimit të tokës. Ato, ndjekin një proçes të trasuar planifikimi, të projektuar për të mënjanuar konfliktet me shfrytëzimin e lëndeve të para. 
Hapi i planifikimit regjional, është veçanërisht i rëndësishëm për të regulluar punët e lëndëve të para. Me ndihmën e një gjendjeje precize, planet regjionale (bazuar në programe më të gjera zhvillimi, si ato nacionale dhe super rregjionale) përcaktojnë objektivat regjionale, të planeve të përdorimit të tokës.

Plani duhet të përcaktojë termin "lëndë të para të zonave prioritare", kështu që këto mund të garantohen, ndërsa duke vleresuar me kujdes, qysh në mesin e periudhës, duhen parë edhe kërkesat afatgjata të resurseve minerale, dhe kushtet e limituara të përvetësimit të vëndburimeve të resurseve minerale.

Zhvillimi i një identifikimi sistematik dhe i vlerësimi të vëndburimeve minerale me sensin e mbrojtjes dhe vlerave, duhet të bëhen filimisht. Kjo duhet të shoqërohet me fazën e dytë të "eliminimit të konfliktit", për të eliminuar ndonjë mbrojtje konfliktesh, të shkaktuar nga zonat minerale. Detyra e fazës se dytë, është të identifikojë "zonat minerale të lira nga konfliktet", duke marrë parasysh sipërfaqe të tjera të mbrojtura me ligj, si p.sh., sipërfaqet rezidenciale, parqet nacionale, zonat me prioritet për menaxhimin e ujrave, sipërfaqet e peisazheve të mbrojtura, pyjet, sipërfaqet e Natura 2000 etj.

Në përcaktimin zona minerale në mbrojtje, do ti jepet vëmëndje speciale, furnizimit regjional të sigurtë dhe adekuat të lëndëve të para të ndertimit, të zbuluara pranë sipërfaqes, që janë për shumë gjenerata. Në sajë të grupeve individuale të lëndëve të para minerale (p.sh. rërë, zhavorr, shkëmb solid, karbonate me kualitet të lartë, argjila, minerale industriale, xeherorët dhe lëndët e para energjetike), duhet të përdoren metoda specifike të vleresimit.

Kur duke përdorur një metodë të një planifikimi pozitiv, prioritete të ndryshme të përdorimit të tokës, mund të reduktojnë vëndburimet, që janë pasuri e nxjerrshme, dhe fushat e mbetura bëhen sipërfaqe të lendëve të para materiale me prioritet. Avantazhi i kësaj metode, është fakti se autoritetet mund të aplikojnë, një politikë konkrete të lëndëve të para minerale. Një problem i planifikimit pozitiv, është spekullimi me tokën.

Përveç kësaj, dhe bazuar në eksperiencën Austriake, duhet të kihet parasysh se shfytëzimi i agregateve, mundet gjithashtu të lejohet jashtë zonës së priotitetit të lëndëve të para minerale, p.sh., në zonë agrokulturore, në se bashkia është dakord. Kjo, sigurisht, varet nga kualiteti i menaxhimit të konfliktit midis operatorit dhe bashkisë (dhe qytetarëve të irrituar) 


\section{Tekst shëmbull:}

Zgjedhja e vëndeve duhet të marrë parasysh politikat nacionale, për peisazhet dhe konservimin natyror apo historik, si dhe për tokën e kultivuar. Planet, duhet të ruajnë gjithashtu, resurset minerale për të punuar në të ardhmen. Planet, duhet të vendosin kriteret e kontrollit të zhvillimit, se cilat kerkesa të reja planifikimi për shfytezimin e mineraleve duhet të kënaqin.

Për qëllimet e Planit Mineral të Resurseve, zonat e lëndëve të para janë përcaktuar të gjitha sipërfaqet, që kanë qenë identiifikuar, duke përdorur metodat analitike objektive dhe sistematike, dhe që përmbajnë lëndët e para minerale. Në pamjen e avancimeve të pritshme teknologjike duke patur në mëndje aspektet ekologjike dhe sociale, pranohet se do të jetë e mundur të përdoret një material i tillë komercialisht nga një periudhë e mesme në të gjatë. Zonat minerale, pasuri e mbrojtur, sikurse përcaktohet nga Plani i Resurseve Minerale, janë ato sipërfaqe minerale, të cilat nuk kanë ose kanë një limit konfliktesh me planet e tjera të përdorimit të tokës. Ato ndjekin gjurmët e proçesit të përvijuar, të planifikimit mineral, për të evituar konfilktet me shfrytëzimin e lëndëve të para. Ato duhet të merren me shfytëzimin e lëndëve të para, por në këtë rast, nuk duhet kërkesë mandatimi për të përdorur aktualisht shfaqet për shfrytezim minerali.

\subsubsection{Identifikimi i burimeve alterrnative}

Duke sjellë një furnizim të qëndrueshëm miks të agregateve, sugjerohet identifikimi i burimeve të qëendrueshme, dytësore të agregateve. Ky aspekt, i referohet strikt strukturës të planit të menaxhimit të mbetjeve (në se ai egziston në vend).

Koha, qëndrueshmëria, politika dhe legjislacioni, duhet të përdoren, me qëllim për të përdorur resurset dytësore sa më shumë që të jetë e mundur. Kjo, sidoqoftë, është edhe një mënyrë e strukturave marketike të riciklimit dhe të çmimeve.

Kjo, jo vetëm redukton nevojën e resurseve parësore p.sh., zgjat përdorimin e resurseve natyrale për gjeneratat e ardhshme, por ajo gjithashtu redukton landfillet. Prandaj, çdo koncept i furnizimit të agregateve, duhet të inkludojë, mjetet e duhura, instrumentet për të rritur përdorimin e resurseve dytësore.

\section{Tekst shëmbull:}

Autoritete e planifikimit të mineraleve duhet të punojnë me organizata të tjera aktuale, për të përdorur informacionin më të mirë të arritshem, që vlerëson kërkesat $e$ projektuara për përdorimin e tyre, duke marrë parasysh, të gjitha oportunitetet për të përdorur materiale nga burime dytësore dhe të tjera, të cilat mund të japin alterrnativa të përdorimit të materialeve parësore. 


\subsubsection{Përcaktimi i kritereve dhe udhëzimeve për sipërfaqet lokale minerare}

Plani duhet të përcaktojë kriteret dhe udhezimet për lokalizimin e sipërfaqeve minerare të rangut të bashkive, bazuar mbi resurset e përdorura, kërkesat e parashikuara, dhe në faktorët e natyrës dhe të mbrojtjes së peisazheve, po ashtu si edhe në nevojat për të konservuar tokën për përdorime të tjera dhe për mbrojtjen e resurseve natyrore (p.sh. tabela e ujrave nëntokësore).

\section{Tekst shëmbull:}

Planet minerare të bashkisë kanë qënë pregatitur mbi bazën e parashikimeve, që përmbahen në planin nacional/regjional, dhe në mënyrë të veçantë, në ato plane, që i referohen identifikimin të zonave parësore.

Plani minerar i bashkisë është i shoqëruar nga një raport spjegues, kartografim aktual dhe standarte teknike të implementimit respektiv, dhe ai identifikon:

a) Sipërfaqe më shumë se në polet te identifikuara nga dyshemeja kryesore, që shpërndahen në aktivitete minerare, brënda limiteve të parcaktuara me ligj, sasira extra, si edhe lokalizimin e sistemeve ndërlidhëse;

b) Përdorimi final i sipërfaqeve të mbuluara nga aktivitetet minerare;

c)Sistemimi i karrjerave dhe marrëveshja finale për të njëjtën gjë duke përfshirë edhe karrjerat e abandonuara;

e) Metodat e menaxhimit;

f) Matjet për të minimizuar impaktet ambjentale të parashikuara.

\subsubsection{Siguro konkurueshmërinë e industrisë të agregateve}

Sikurse shprehet nga PG (European Aggregates Producers Association), dhe kjo do të thote "jo ndërtime pa agregate" . Duke qënë se sot, industria e agregateve është burimi më i rëndësishëm i lëndëve të para (Bressi et al. 2011) dhe rregullues i tregut (ose ç'rregullues), është dhe çelësi për të siguruar konkurueshmërine dhe të promovosh përafrime të qëndrueshme.

Siguracioni i investimeve për operatorin është i rëndësishëm. Kur granti minerar premton për karriera të shkëmbinjve të fortë (p.sh. rezerva të aprovuara të agregateve), një periudhë 50-vjecare në shkallën kohore duhet të jetë tipike për tu marrë në konsideratë. Nuk duhet të ketë leje minerare për më pak se 15 vjet, përndryshe pjesa më madhe e kapitalit të investuar nuk mund të justifikohet.

Në ndonjë rast, kohëzgjatja e çdo leje, duhet të vlerësohet duke marrë parasysh, volumin e gatshëm të agregateve, nevojat e pritshme dhe teknikën më të mirë, të 
qëndreushme, të mundshme, të shfrytezimit. Për gërmimet e rërës dhe zhavorrit, kohëzgjatja e lejes duhet të jetë 10-15 vjet, në varësi të shkallës së vëndburimit, me rinovim të mëtejshëm, që do të jetë në proporcion me madhësine e vëndburimit. Kohëzgjatja e lejes minerare, duhet të jetë gjithënjë në linjë me jetëgjatësinë e vëndburimit: qëndrueshmëria kërkon shfrytëzimin e të gjithë vendburimit (Cibin et al., 2011).

Në këtë vështrim, disa efekte mund të shprehen vecanërisht në termat e vëndburimeve të pa litifikuara, si vëndburimet e rërës dhe zhavorrit, dhe në konfliktin potencial me resurset e furnizimit më ujë, në praktikat konservbimit të peisazheve, praktikat e reduktimit të impakteve ambientale, dhe në praktikat e restaurimeve të mira. Këto efekte mund të çojnë në shrytëzimin e pjesshëm të vëndburimit.

Duhet të shënohet se përdorimi i integruar i agregateve natyrale dhe atyre të ricikluara, përveç një ruajtjeje të konsiderueshme të resurseve natyrore, do të mundësonte një shfrytëzim më të mirë të resurseve të mundshme, në përputhje me përdorimet e ndryshme.

Në tregun e lirë, ka një seri faktorësh, të cilët duhet/mund të favorizojnë përdorimin e agreagteve të ricikluara kundrejt atyre natyrale. Kjo inkludon:

- Një çmim më të ulëte se materialet natyrale të çvendosura;

- Një kërkesë më të madhe për materiale për shtrimin e rrugëve, rimbushjes, dekoreve, barrjerave etj.;

- Reduktimi i kostove të transportit (që mund të jenë më të ulëta për arësye se operacioni i riciklimit, është, zakonisht ngjitur me karrjerën dhe që mund të anullohet në rastin e prodhimit në vënd)

- Cmimi i ulët, është pa dyshim treguesi më i rëndësishëm në rastin e produktit të ricikluar, për deri sa ai prezanton njërin nga faktorët deçizivë në grantet e tenderave. Për më tepër, qeveritë munden gjithashtu të zhvillojnë politikat e GPP (Green Public Procurement), për të misionuar një sërë qellimesh, përfshi një rritje të përqindjes të konsumit të materialit të ricikluar, në shumë aktivitete konsumi, dhe një rritje të efiçencës së resurseve. Kur duke u marrë me GPPs, një tejkalim në kostot e kapitalit fillestar, për shëmbull, mund tu shkaktojë zyrtarëve të prokurimit të favorizojnë një devizë më pak eficiente-energjetike, bile edhe kur divizat më efiçiente mund të ruajnë resurset qeveritare, kundrejt një ecje të gjatë. Tashmë mendohet, se ky nuk është rasti me agraegatet e ricikluara, kështu ky është një konditë "fitim-fitm". 
- Më në fund, për një mbulim të pjesëshm të kostove të produktit, të lidhur me punën që është e domosdoshme të garantojë konstanten e karakteristikave të agregateve të ricikluara (Kontrollin e Produktit në Fabrikë), prodhuesi, mundet gjithashtu të mbeshtetet në çmimet e aplikuara në mbetjet e disponuara për përdorim në uzinë, e cila, megjithëse e limituar, mundëson kryerjen e operacionit, të pakten në çdo vënd lokal.

\section{Tekst shëmbull:}

Kohëzgjatja e autorizimit dhe në konventat aktuale nuk mund të jetë më shumë se 50 vjet, as, si rregull, më pak se 10 vjet. Ne e njohim nevojën për të vepruar në përputhje me principet e zhvillimit të qëndrueshëm dhe të mbrojmë dhe konservojmë ambjentin: plani do të adresojë rrugët për përmirësimin e perfomancës ambjentale të produktieve, nëpërmjet cikleve të tyre të jetës; kjo do të përmbledhë aksionin mbi inisiativat ekonomike për produkte miqësore me ambjentin, duke përmirësuar kërkesat e "gjelbërta" nëpërmjet një informacioni më të mirë konsumimi, duke zhvilluar një bazë objektive për prokurimin e publikut të gjelbërt, dhe aksionin për të dhënë kurajo proçedurave më miqësore ambjentale të prodhimit. .

\subsubsection{Adoptimi i teknologjive me të mira, të gatshme, gjatë gjithë proçesit}

Shumë teknologji egzistojnë me qëllim që të reduktojnë impaktet indirekte (të lidhura me operacionet e gërmimit dhe transportimin e agregateve) në atmosferë, në ujrat sipërfaqësore dhe në biosferë.

Zakonisht, kompanitë investojnë në teknologjitë e gatshme, më të mira, kur është e domosdoshme të kënaqin urdhërat rregullues dhe të mënjanojnë gjobat financiare, të vëna nga ligji. Me një edukim konkret, operatorët mund të fillojnë të bëhen një aktor aktiv në proçesin e prodhimit më të qëndrueshëm të agregateve. Për më tepër, shumë kompani do të kontribuojnë më shumë se organet lokale të obliguara, për komunitetet lokale, si bashkëfinancues të sporteve dhe aktiviteteve kulturale, ose aktiviteteve të ngjajshme, dhe të mbajnë marrëdhënie të mira më komunitetin lokal.

Operatorët e karrierave, duhet të jenë të qartë, se zëri ambjental dhe publik në shfrytëzim, është vital për të ardhmen e kompanisë. Kompanitë sot, janë duke u përpjekur, në pergjithësi, ti mbajnë "Përgjegjësitë Sociale të Korporatës" në nivele të larta. Rrjedhimisht, biznesi do të mund të përqafonte përgjegjësitë për impakt të aktiviteteve të tij, në ambjent, të konsumatoreve, të punesuarve, komunitetit dhe grupeve të interesit.

Me prodhimin primar të agregateve, proçesi mund të ketë çertifikimet ambjentale (ISO 9000/ISO 14000), të bazuara, në kërkesa specifike teknike dhe ambjentale. Ekstrakti mund të bëhet, në atë mënyrë, që të prodhohet sasia minimum e mbetjeve. 
Gjithashtu, në fushën e prodhimit tëe agrgateve dytësore egzistojnë shumë teknologji në gjëndje të mirë (state-of-the-art), dhe mund të punësohen gjatë trajtimit të C\&DW , me qëllim që të prodhohet kualitet i mirë i agreagteve të ricikluara, që mund të konkurojnë me produktet e karrjerës, në terma të vetive teknike. Këto teknologji, janë të mundshme edhe në formen e uniteve të uzinave me proçes të levizshem, që mund te montohen ne vënd, ose si fabrika stacionare, speciale, të riciklimit.

Instrumentat e planifikimit, mund të japin një zgjidhje për të vlerësuar perfomancen e një fabrike përpunimi, me vënien e indikatorëve, që duhet të vlerësohen në kohën e autorizimit.

Megjithëse ky nuk është pjesë e një plani mineral, duhet shënuar se metodologjia e aplikuar për shkatërrim, ndikon ndjeshem në perfomancën e proçesit pasardhës të riciklimit dhe në veçoritë teknike të produkteve të ricikluara. Sortimi paraprak $i$ C\&DW në vëndburim, në segmente homogjene, redukton riciklimin ose kostot ( $k u$ janë aplikuar) e vëna dhe siguron një kualitet më të mirë për produktet e ricikluara. Kjo duhet të integrohet në planin e mbetjeve, për të maksimizuar mbi të gjitha efiçiencën.

\section{Tekst shëmbull:}

Plani nacional përcakton nevojat për planet e detajuara bashkiakë, mendohet një raport spjegues, një kartografim i mjaftueshëm dhe standartet teknike respektive të implementimit për metodën e hapjes së karrjerave, vëndi përfundimtar $i$ karrjererave, përfshi karrjerat e abandonuara.

\subsubsection{Përcktimi i kritereve për përdorim pas mbylljes}

Aktivitetet minerare, janë domosdoshmërisht të shoqëruara me impakte në sipërfaqe. Kjo aplikohet veçanerisht, në rastet e përdorimit të përkohshëm të sipërfaqes nga minierat me qiell të hapur, por gjithashtu edhe në rastet e përdorimit për një kohë të gjatë apo permanent, dhe të tilla raste të demtimit jane të shumta.

Përcaktimi i një plani të restaurimit gjatë planifikimit për hapjen e karrjerave të ardhshme, duhet të siguiroje se karrjerat e shfrytëzuara, nuk do të bëhen vënde të mbetjeve të pakontrolluara. Për tu siguar për këtë, që një plan restaurimi do të aktivizohet, është e domosdoshme të sigurojmë resurset ekonomike, p.sh., garancitë.

Për të arritur rezultate më të mira në rehabilitim dhe restaurim të vëndeve të shfrytëzuara, plani i restaurimit duhet të plotësojë kushtet speciafike ambjentale për seicilin vënd.

Në se një mbulim komplet nuk është i mundshëm, ngritja e fabrikave të riciklimit në 
karrjerat e abandonuara, duhet të mendohet kur të vlerësohet përdorimi i tyre pas mbylljes.

\section{Tekst shëmbull:}

Sipas Ligjit Minerar, aktiviteti minerar nuk mbaron me nxjerrjen e resurseve minerale dhe mbylljen e karrjerës. Rehabilitimi, përbën një pjesë integrale të aktivitetit minerar. Operatorët e minierës, sipas ligjit, duhet të reabilitojnë të gjitha vëndet $e$ shfrytëzuara. Interesat e komunitetit të prekur dhe të ekosistemeve janë marrë parasysh qysh në fazën më të hershme, në fazën e planifikimit, para se tëfillonte shfrytëzimi.

\subsubsection{Koordinimi i autorizuar midis autoriteteve të lejeve}

Ndoshta është mirë të përmirësohet koordinimi midis proçedurave të lejimit të autoriteteve dhe menaxhimit të planifikimit të perdorimit të tokes. Një politikë e kohës, e planifikimit të agregateve duhet të bazohet në të dhënat dhe në informacionet aktuale (gjeologjia, lokalizimi, sasia dhe cilësia e vëndburimeve minerale, që zakonisht janë të njohura mirë). Kufizimi i përdorimit të tokës dhe sipërfaqet e mbrojtura, kështu do të kihen parasysh për të përcaktuar potencialin e resurseve të agregateve të një zone.

Për deri sa potenciali i resurseve është vlerësuar, atëhere njohja preçize e kërkesave për agregate, informacioni për sasinë e prodhuar të agregateve, dhe një informacion për tempet e riciklimit në nivel prefekture, kërkohet të finalizojnë planin, sidoqoftë, këto të dhëna, kërkojnë një koordinim të fortë midis autoriteteve të ndryshme.

Per më tepër, ligji nuk duhet të gjenerojë mbulimin, e përgjegjësive administrative midis autoriteteve të ndryshme të planifikimit. Në pikpamje hierarqike, një plan lokal duhet të adaptohet qartë në kornizën e planit nacional.

Zakonisht, plani principial duhet të merret me parashikimet kërkesa/oferta, import/eksport dhe dokumentet ndërkufitare, me balancet ekonomike, sociale dhe ambjentale, si edhe me një marrëdhënie strikt me planifikimin e përdorimit të tokës p.sh. në identifikimin e "zonave prioritare të agregateve".

Disa aspekte aktuale për SARM dhe SSM, duhet të jenë pjesë e Legjislacionit Minerar Nacional/Regjional (dhe të reflektohen në plane), përfshi:

- Efiçienca e resurseve, duke përjashtuar mbetjet;

- Përdorimi i standarteve më të mira teknike, ambjentale;

- Konceptet e transportit sipas principeve të trafikut bashkiak; 
- Garantimi i fondeve për restaurim;

- Veçanërisht konsideratat e planifikimit të përdorimit të tokës në proçedurat e lejeve;

- Interesi publik, që mund të konsiderohet në nivel më të gjerë.

Planet minerare të Bashkisë do të përshkruajnë me më shumë detaje kornizën e përcaktuar nga plani dhe me një përafrim të decentarlizuar, këto plane më në fund, identifikojnë sipërfaqet potenciale të mundshme për shfytëzim nga entitete private. Plani i restaurimit, zakonisht, inkludon vlerësimin e impaktit ambjental si edhe disa masa për ti reduktuar impaktet.

\section{Tekst shëmbull:}

Plani Bashkiak (i agregateve) është pregatitur bazuar në planin provizor që përmban Plani Nacional, dhe në mënyrë të veçantë në ato që i përkasin shfrytëzimit në zonat prioritare të agregateve. Plani Bashkiak është adoptuar dhe miratuar, me proçedurat e dhëna për skemën e planit të përgjithshëm; trupi mbikqyres në këtë rast është Komisioni teknik (nacional) për aktivitetet minerare.

Ai vendos Komisionin teknik (minerar) per aktivitete minerare, me pergjegjesi keshilluese, në rastet e dhëna në ligj.

Komisioni mban zyrë për pesë vjet dhe perbëhet si më poshtë:

a) Nga këshilli regjional ose që ka juridiksion në këtë subjekt, duke vepruar si Kryetar; komisioneri mundet në mungesë të tij, të zëvëndësohet nga një zëvëndës, i zgjedhur ndërmjet njerit prej anëtareve të vet komisionit;

b) Nga pesë ekspert në disiplinat e gjeologjisë, minierave, agrikulturës dhe pyjeve, ekonomisë, legjislacionit, planifikimit ambjental dhe atij territorial-urban, i zgjedhur nga Këshilli Regjional midis akademikëve dhe teknikëve me ekspertize shkencore të provuar dhe me eksperiencë profesionale;

c)Nga tre ekspert të të njëjtave disiplina, të zgjedhur nga Këshilli Regjional, nga stafit në shërbim, me fuqi regjionale, të ingrenuar në materialet.

\subsubsection{Procedurat e lejeve duhet të jenë eficiente dhe efektive}

Eshtë propozuar një përafrim me një market me një ndalesë, ku të gjitha departamentet e inkluduara, koordinojnë me efiçiencë me njëri tjetrin. Gjithashtu është marrë përsipër, që proçedurat e lejeve do të bazohen në planifikimin dhe menaxhimin e përdorimit të tokës, të paktën në termat e zonave prioritare, të seleksionuara, të lendëve të para. 
Nga pikpamja e planifikimit, përjashtimet ligjore nuk do të lehtësonin identifikimin e sipërfaqeve të volitshme për shfytëzim dhe do të mund ti mënjanonin në se do të ishte e mundur.

\section{Tekst shëmbull:}

Një ushtrim i aktivitetit minerar është lejuar, i dhënë me autorizim të Kryebashkiakut (ose autoriteti tjetër), eksluzivisht në sipërfaqet e specifikuara në Planin e aktiviteteve minerare, mbi bazën e keshillës së Komisionit Teknik për aktivitete minierare, dhe pas përcaktimit të një konvente midis konçensionarit dhe shtetit.

\section{Shembëll përjashtimi:}

Eshtë një rast përjashtimi, që konsiston në shfytëzimin e resurseve të agregateve të vendosura në sipërfaqet e klasifikuara si pronë shterore për legjislacionin (prona shterore është pronë e lëvizshme ose e palëvizshme, që u përket pushteteve lokale, në emër të shtetit, rajoneve, provincave dhe bashkive). Këto agregate janë kështu, pronë e entitetit publik, zotërues i tokës, zakonisht liqene, lumi apo brigjet e tij. Në këtë rast, pushteti lokal, që mund të lejojë shfrytëzimin në raste të sigurta dhe nen kushte të sigurta (p.sh. si nënprodukte të ruajtjes, dhe ndërhyrje hidraulike, që ndihmon në një sistem uji funksional ose vendosje linjas uji).

\subsubsection{Përforcimi i nevojave për një balancë ambjentale}

Plani duhet të integrojë vlerësimin e impaktit ambjental (EIA) në proçedurën e skeletit të planit të operacioneve me parshikim specifik, duke llogaritur karakterin dinamik të aktiviteteve minerare. Plani duhet të përmbajë një list të projekteve të mundshme minerare që do të jetë subjekt i një EIA (në përputhje me përmasat ose volimin që do të shfrytëzohet). Me qëllim që të garantohet pjesëmarrja e publikut dhe të të gjithë grupeve të interesit, aprovohen operacionet skeletore me një EIA nga autoritetet minerare, Kjo është subjekt për një plan proçedure miratimi formale, me grumbullimin e të gjitha lejeve paralele të inkluduara (marketi me një ndalesë). Kjo proçedurë lejon që të gjitha dokumentet e inkluduara të egzaminohen me të gjithë administratën dhe me grupet e interesit dhe i jep investitorit një siguri legale.

\section{Tekst shëmbull:}

Të gjitha projektet e shfytëzimit mund të bëhen subjekt i proçedurave te EIA, në se ato përmbajnë karriera me më shume se $500,000 \mathrm{~m}^{3} / v i t$ material $i$ shfytëzuar ose me veprim në një siperfaqe prej më shumë se 20 ha. 


\section{Referenca}

- $\quad$ Agioutantis, Z. et al. (2014). Handbook on Data and Analysis Methodologies for Aggregates Planning: A joint manual for planning authorities in SEE region, SNAP-SEE.

- $\quad$ Cibin, U., Cera, M.C., Spotorno, C., Furin, S., Pelosio, A. , Romagnoli, M., Rizzati, A.R. \& Marasmi, C. (2011). SARMa Activity 4.2 (SSM) Synthesis Report. http://www.sarmaproject.eu/uploads/media/SARMa_Report_Sustainable_Supply_Mix_0 1.pdf

- $\quad$ Council Directive 89/106/EEC of 21 December 1988 on the approximation of laws, regulations and administrative provisions of the Member States relating to construction products. Official Journal L 40, 11.02.1989, p. 12-26. http://eur-lex.europa.eu/legalcontent/en/ALL/?uri=CELEX:31989L0106

- CSES 2014. Final Report on "Evaluation and Exchange of Good Practices for the Sustainable Supply of Raw Materials within the EU" - ANNEX A - GOOD PRACTICE CASES. Centre for Strategy and Evaluation Services.

http://ec.europa.eu/DocsRoom/documents/4878/attachments/1/translations/en/renditi ons/pdf

- Dolinar U., Softič M. \& Kozinc Z. (2014). Handbook on Consulting Stakeholders when Applying Best Practices in Sustainable Aggregates Planning, SNAP-SEE, 2014

- $\quad$ EC (2011). Resource-efficient Europe - MEMO/11/43 26/01/2011. European Commission. http://europa.eu/rapid/press-release_MEMO-11-43_en.htm?locale=en

- Hámor, T., Tiess, G., Kager, J. \& Heimburg, J. (2011). European Community Law relevant to aggregates: SARMa - Review of EU Community Legislation - A framework recommendation. http://www.sarmaproject.eu/uploads/media/SARMa_Report_EU_Law.pdf

- Hámor, T. (2012). Recommendations for effective aggregate policy and management, covering the legal and regulatory solutions with regard to sustainable aggregate resources management.

http://www.sarmaproject.eu/uploads/media/SARMa_Recom_Aggreg_Policy_01.pdf

- $\quad$ Horváth, Z., Miko, S., Sári, K. \& Dedić, Ž. (2014). A Vision of Best Practices for Aggregates Planning in South East Europe, SNAP-SEE, Ljubljana, 56 p.

- $\quad$ IISD (2004). National Strategies for Sustainable Development: Challenges, Approaches and Innovations in Strategic and Co-ordinated Action. International Institute for Sustainable Development. IISD, Winnipeg, CA.

- Tiess, G. (2010). Minerals Policy in Europe: Some Recent Developments. Resour. Policy 35, 190-198.

- $\quad$ UEPG (2010). Planning Policies and Permitting Procedures to Ensure the Sustainable Supply of Aggregates in Europe. http://www.minpol.com/LeobenReview_finalfinal_060610.pdf

- Weber, L. (2012). Der Osterreichische Rohstoffplan Archive fur Lagerstattenforschung 26, 264 S. Geol B-A, Wien (The Austrian Mineral Resources Plan). Arch. f. Lagerst. forsch Geol. B.-A. Band 26, pp. 1-264. Wien.

http://opac.geologie.ac.at/wwwopacx/wwwopac.ashx?command=getcontent\&server=i mages\&value=AL0026_001_A.pdf 



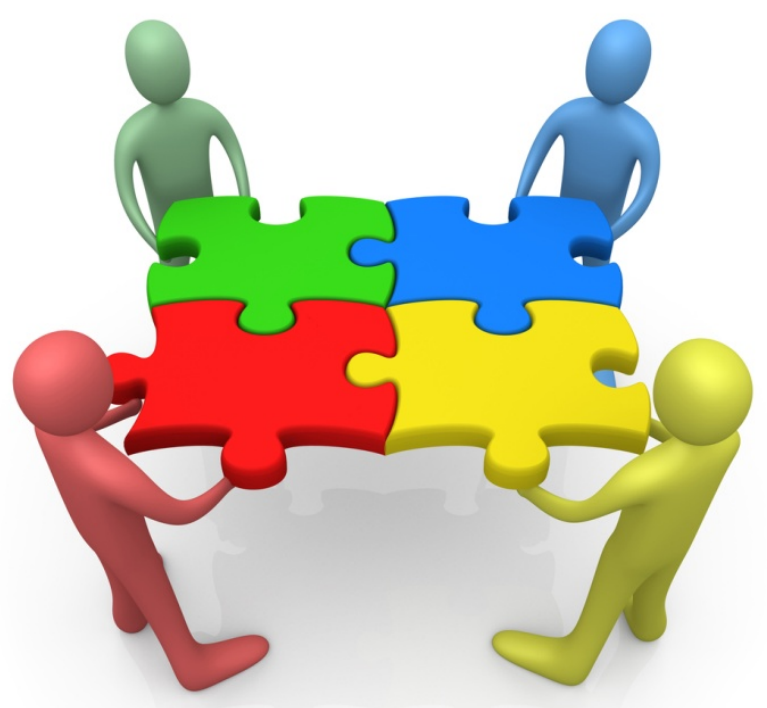

Planifikimi i Qëndrueshëm i Agregateve në Europën Juglindore (SNAP-SEE) http://www.snapsee.eu 